\title{
Advanced Hydrogels for Cartilage Tissue Engineering: Recent Progress and Future Directions
}

\author{
Mahshid Hafezi ${ }^{1}$ (D), Saied Nouri Khorasani ${ }^{1, *}$, Mohadeseh Zare ${ }^{2}$, \\ Rasoul Esmaeely Neisiany ${ }^{3}$ (i) and Pooya Davoodi ${ }^{4,5, *(\mathbb{C})}$ \\ 1 Department of Chemical Engineering, Isfahan University of Technology, Isfahan 84156-83111, Iran; \\ mahshid.hafezi96@pa.iut.ac.ir \\ 2 School of Metallurgy and Materials, University of Birmingham, Birmingham B15 2TT, UK; \\ m.zare@bham.ac.uk \\ 3 Department of Materials and Polymer Engineering, Faculty of Engineering, Hakim Sabzevari University, \\ Sabzevar 96179-76487, Iran; r.esmaeely@hsu.ac.ir \\ 4 School of Pharmacy and Bioengineering, Hornbeam Building, Keele University, Staffordshire ST5 5BG, UK \\ 5 Guy Hilton Research Centre, Institute of Science and Technology in Medicine, Keele University, \\ Staffordshire ST4 7QB, UK \\ * Correspondence: saied@iut.ac.ir (S.N.K.); p.davoodi@keele.ac.uk (P.D.)
}

Citation: Hafezi, M.; Nouri Khorasani, S.; Zare, M.; Esmaeely Neisiany, R.;

Davoodi, P. Advanced Hydrogels for Cartilage Tissue Engineering: Recent Progress and Future Directions. Polymers 2021, 13, 4199. https:// doi.org/10.3390/polym13234199

Academic Editor: Elisabetta Ranucci

Received: 8 November 2021

Accepted: 24 November 2021

Published: 30 November 2021

Publisher's Note: MDPI stays neutral with regard to jurisdictional claims in published maps and institutional affiliations.

Copyright: (c) 2021 by the authors. Licensee MDPI, Basel, Switzerland. This article is an open access article distributed under the terms and conditions of the Creative Commons Attribution (CC BY) license (https:// creativecommons.org/licenses/by/ $4.0 /)$.

\begin{abstract}
Cartilage is a tension- and load-bearing tissue and has a limited capacity for intrinsic selfhealing. While microfracture and arthroplasty are the conventional methods for cartilage repair, these methods are unable to completely heal the damaged tissue. The need to overcome the restrictions of these therapies for cartilage regeneration has expanded the field of cartilage tissue engineering (CTE), in which novel engineering and biological approaches are introduced to accelerate the development of new biomimetic cartilage to replace the injured tissue. Until now, a wide range of hydrogels and cell sources have been employed for CTE to either recapitulate microenvironmental cues during a new tissue growth or to compel the recovery of cartilaginous structures via manipulating biochemical and biomechanical properties of the original tissue. Towards modifying current cartilage treatments, advanced hydrogels have been designed and synthesized in recent years to improve network crosslinking and self-recovery of implanted scaffolds after damage in vivo. This review focused on the recent advances in CTE, especially self-healing hydrogels. The article firstly presents the cartilage tissue, its defects, and treatments. Subsequently, introduces CTE and summarizes the polymeric hydrogels and their advances. Furthermore, characterizations, the advantages, and disadvantages of advanced hydrogels such as multi-materials, IPNs, nanomaterials, and supramolecular are discussed. Afterward, the self-healing hydrogels in CTE, mechanisms, and the physical and chemical methods for the synthesis of such hydrogels for improving the reformation of CTE are introduced. The article then briefly describes the fabrication methods in CTE. Finally, this review presents a conclusion of prevalent challenges and future outlooks for self-healing hydrogels in CTE applications.
\end{abstract}

Keywords: polymeric hydrogels; self-healing; articular cartilage; tissue engineering

\section{Introduction}

Cartilage defects as a result of aging and degenerative pathology, sports-related injuries, unexpected events, fatness, diseases, etc. have been noticed for more than 200 years. Non-vascular and finite cellular tissue of cartilage causes its limited regeneration [1]. With the growth of the elderly population in recent years, it is predicted that more than $15 \%$ of people aged 60 years and older (nearly 310 million people) will develop cartilage-related problems [2]. Although surgical methods, such as cartilage chondroplasty and microfractures, have been developed to treat cartilage defects, they have been unable to entirely repair the damaged cartilage. The current restrictions of cartilage surgery, such as complicated surgical procedures, post-infection, risk of the immune response, and poor-quality 
of the regenerated cartilage, have created a research field in tissue engineering and biological sciences to advance new cartilage tissue treatments [1-3]. However, the important constraint limiting CTE outcomes is the poor cell migration and growth inside implanted scaffolds, which yields new cartilage with undesirable physiological properties [2,3].

Hydrogels are appearing as an attractive class of biomaterials for organ regeneration and tissue repair due to interesting properties including tunable elasticity and stiffness, high-water content (typically 70\%-99\%), excellent biocompatibility, biodegradation, etc. Their three-dimensional (3D) network structures are made of natural macromolecules and/or synthetic polymers upon physical/chemical cross-linking [4]. The mechanical strength of the natural hydrogel scaffolds can range from 0.45 to $5.65 \mathrm{MPa}$ [4] while synthetic hydrogels could attain 15-125 MPa [4]. In recent years, hydrogels for various biomedical applications have been prepared via the blending of both natural and synthetic polymers, thereby permitting the regulation of the physical and chemical characteristics of final products to meet their ultimate application [5]. Hydrogel properties can also be modified through chemical functionalization and physical manipulation (e.g., scaffolding) to mimic physicochemical and biological properties desired for a particular tissue construct $[4,5]$.

Self-healing ability is one of the interesting properties of native tissues to repair injuries. Due to tensions and stresses exerted during physical activities, implanted hydrogels usually experience microcracks and structural defects. These microcracks gradually grow in size and finally yield to failure of the hydrogel structure [6]. Tissue engineering has taken a novel path for the regeneration of cartilage by using self-healing hydrogels. Self-healing hydrogels offer unique benefits such as self-repairing of damages, retaining structural integrity, and long-term functionality [7-9]. Despite many similarities between synthetic self-healing hydrogels and the extracellular matrix (ECM), hydrogels have demonstrated some drawbacks such as insufficient mechanical strength, low fracture energies $\left(<15 \mathrm{~J} \mathrm{~m}^{-2}\right)$, low cell viability, etc. [10]. As presented by some researchers, self-healing hydrogels with tunable mechanical properties have gained significant attention in tissue engineering and are desirable for organ regeneration, particularly for CTE [4,11,12].

The timeline of the major developments in CTE is presented in Figure 1. It started with the simple definition of hydrogel in 1960 and has reached the novel bioprinting for CTE using advanced hydrogels. Its focus on CTE for cartilage repairing also briefly addresses the development of hydrogels for CTE applications. Several review papers studied different natural and synthetic biopolymers and their properties, their recent advances including nanocomposites and interpenetrating networks, etc., fabrication of hydrogel scaffolds, and fillers utilized as hydrogel components for cartilage repairing [13-16]. Additionally, some papers considered self-healing hydrogels in tissue engineering. However, these articles did not provide an overall and comparative classification of the self-healing hydrogel for CTE application, which is essential from the material selection point of view. While several research groups have comprehensively reviewed self-healing materials, these publications have rarely focused on applying such systems in CTE. In the current manuscript, we concisely explained self-healing hydrogels in CTE. This review summarized the latest efforts for the preparation of hydrogels for cartilage-repairing applications, with a particular focus on advanced self-healing hydrogel. Therefore, the outstanding goal of the current review was to reinforce the importance of modification and improvement of the highperformance hydrogels in CTE. 


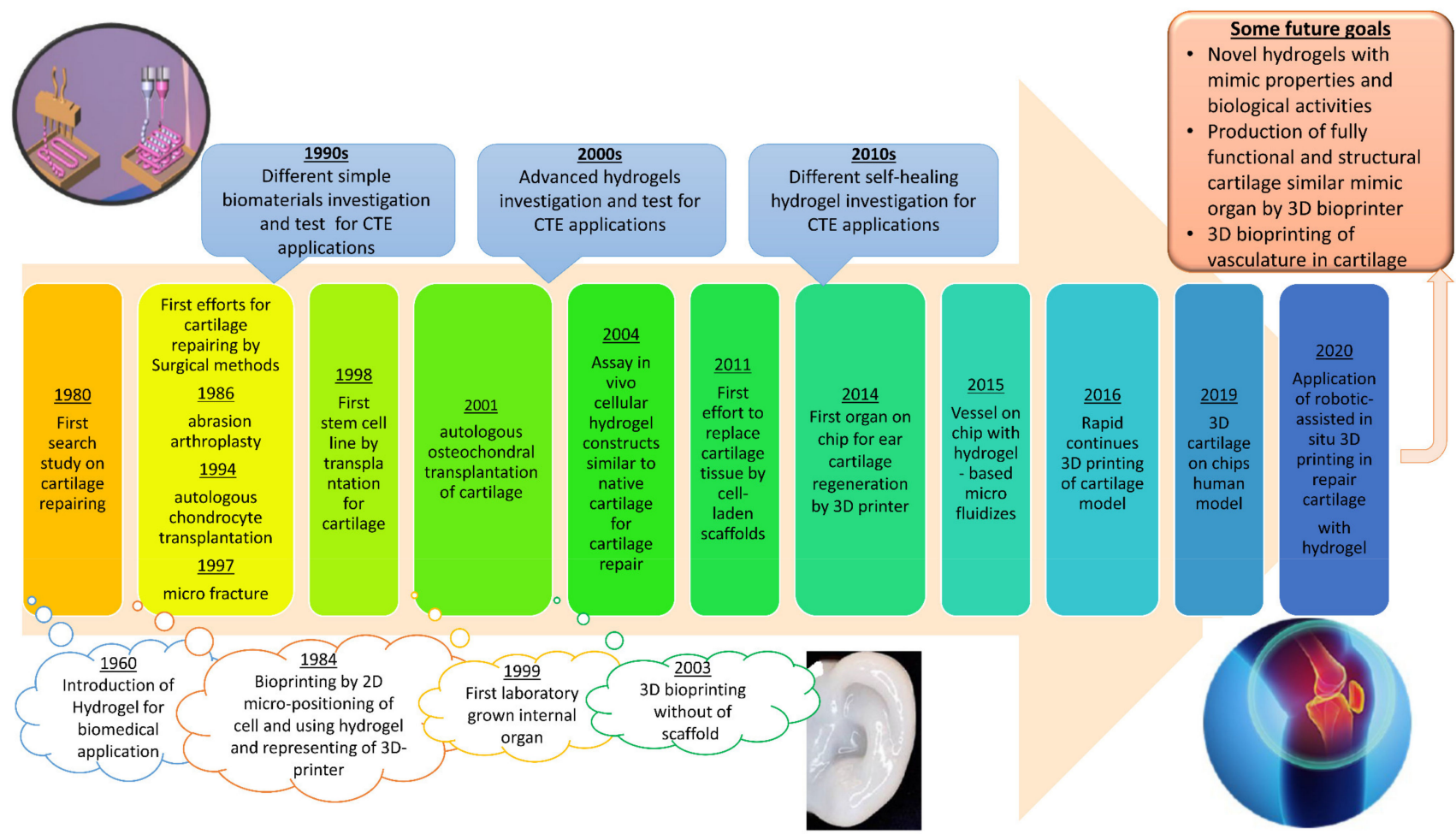

Figure 1. A timeline for the most important developments in the history of cartilage repairing with focus on hydrogel-based CTE. Reproduced with permission from Refs. [16,17].

\section{Cartilage Structure}

The main role of cartilage is to create a low-friction area inside synovial joints that provides the skeleton connections with load transmission capabilities during a range of motions in different activities [14]. The cartilage has a complex avascular and aneural structure. The superficial (external), the middle (central zone), the deep zone, and the calcified zone are the four basic layers of cartilage wherein their thickness depends on the ECM contents, structure, and chondrocyte status. Figure 2A,B shows components and various types and the four main zones of hyaline cartilage tissue [3].

In general, this complex texture is composed of water, various types of collagen, proteoglycans, and chondrocytes. The interaction of these components during cartilage formation leads to the formation of a robust tissue construct that can tolerate the incoming mechanical tensions and loads $[3,18]$. For example, articular cartilage tissue contains $70 \%-85 \%$ water and $60 \%-70 \%$ (of the dry weight of cartilage) collagen [19]. While collagen type II is the basis for articular cartilage and hyaline cartilage, collagen types I, III, V, VI, IX, XI-XII, and XIV also exist in the cartilage. Proteoglycans, as the next prevalent portion of cartilage, comprise around $30 \%$ of the dry weight of cartilage and are made of hyaluronic acid (HA) backbone with sulfated glycosaminoglycans (GAGs) branches [18]. The mentioned portions together are considered as ECM. Chondrocytes produce the ECM components; however, they organize $2 \%$ of the volume of mature cartilage [2].

An amorphous layer on the outer surface of the cartilage protects the cartilage surface and plays an essential role in lubricating the knee joint. This layer has approximately equal quantities of glycosaminoglycan (GAG), protein, and lipid [20]. Articular cartilage is also surrounded by a synovial fluid-made of water, hyaluronan, proteins, proteoglycans, and lipids-which acts as a lubricant to reduce friction between cartilage and meniscus surfaces [21]. 
A)

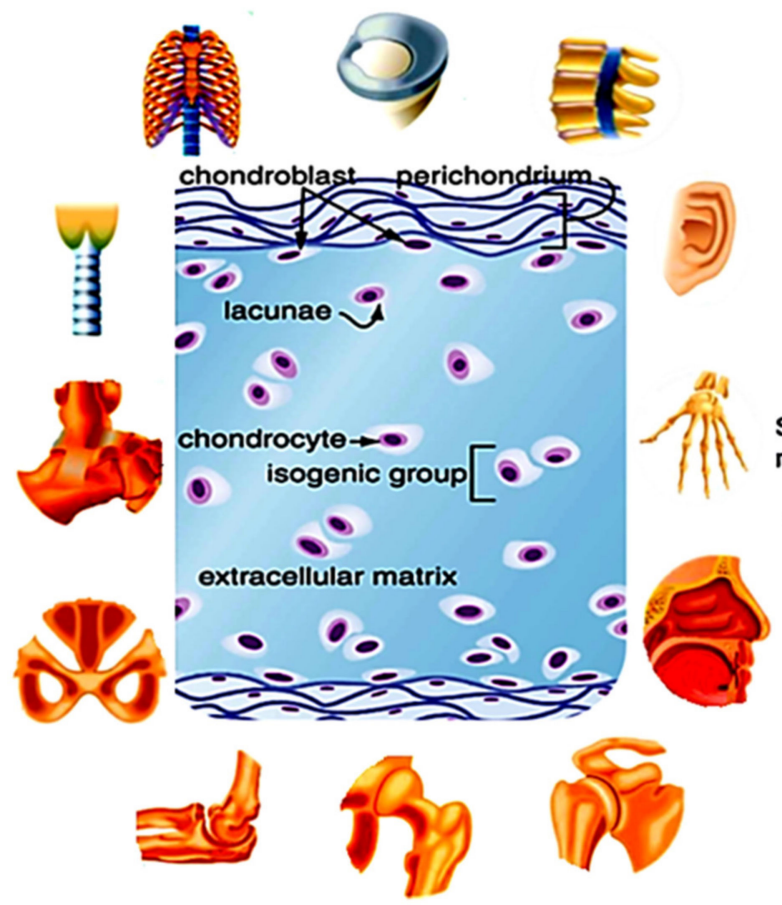

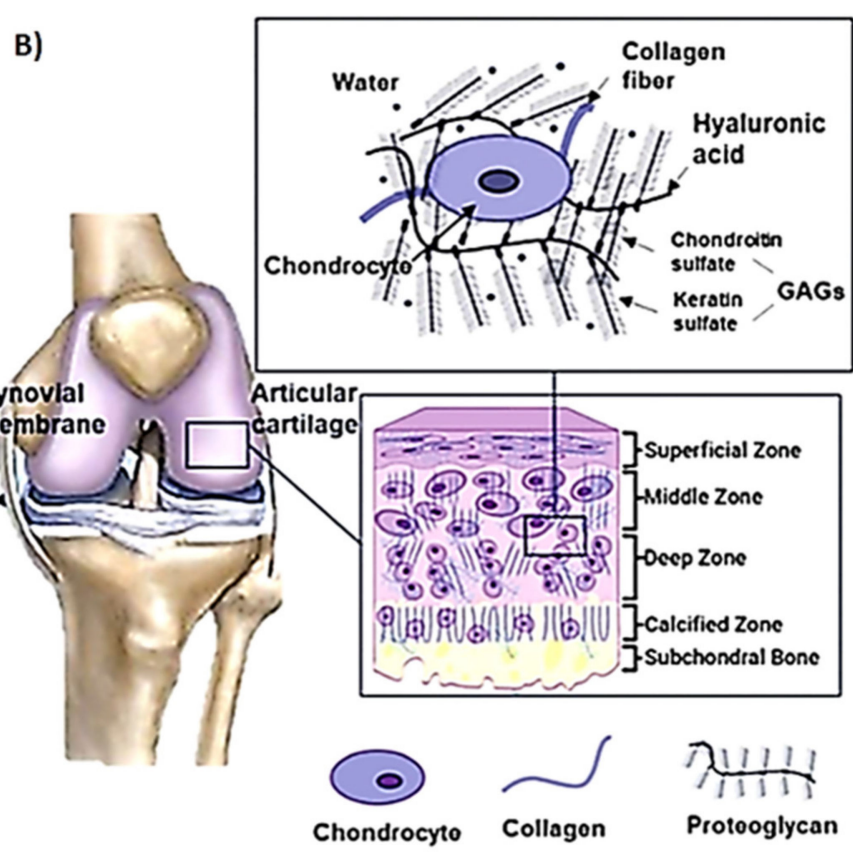

Figure 2. (A) Cartilage tissue component and its types in the human body; (B) main layer of hyaline cartilage tissue. Reproduced with permission from Refs. [3,22].

\subsection{Mechanical Properties of Cartilage}

Articular cartilage made of a proteoglycan gel reinforced matrix by collagen fibers has the main task of load bearing and its distribution in the knee. Articular cartilage dis-plays properties such as high stiffness (fracture energy (toughness) $\geq 1000 \mathrm{~J} \mathrm{~m}^{-2}$ [20], stiff-ness $\geq 1 \mathrm{MPa}$ [22]), and high tensile resistance ( $\geq 30 \mathrm{MPa}$ ) [21]. Tensile elongation of up to $140 \%$ limits its stretchability [23]. The most important factors in the design of the cartilage scaffolds are biocompatibility, biodegradability, enhanced cell differentiation, stability, suitable mechanical properties and porosity, cell adhesion, and accretion with the adjoining native cartilage [22,23]. Currently, design views for tough hydrogels have been focused on the effective damping of mechanical energy around the damaged area through the fracture of weak bonds. Tensile, compressive, permeability, and shear tests are the main techniques to determining cartilage mechanical properties and highly depend on test methods [24]. Additionally, the types of cartilage, strain value, depth from the articular surface, and maturation of cartilage tissue affect tensile, compressive modulus, and permeability of cartilage tissue. A wide range of $0.08-2.5 \mathrm{MPa}$ is reported for the confined equilibrium compression modulus (for superficial and deep zones of cartilage, respectively). Additionally, the tensile modulus of the superficial layer in mature human cartilage is $25 \mathrm{MPa}$, while it is $5.5 \mathrm{MPa}$ in the middle zone and $4.5 \mathrm{MPa}$ in the deep layer. The hydraulic permeability varies between $0.3 \times 10^{-17}$ to $4.6 \times 10^{-15} \mathrm{~m}^{2} /$ (Pa. s) in articular cartilage [21,24,25], $11.15 \times 10^{-16}-15.85 \times 10^{-16} \mathrm{~m}^{2} /$ (Pa. s) in the knee joint [26], and $0.9 \times 10^{-17}-2.9 \times 10^{-15} \mathrm{~m}^{2} /(\mathrm{Pa} . \mathrm{s})$ in nose cartilage [27].

Mechanical properties including the equilibrium shear modulus, Poisson's ratio, and aggregate modulus change notably for different joint positions. Additionally, these properties are dependent on the anisotropies existing within the cartilage, the sample area, and the sample orientation in test machines [21]. Some properties of cartilage, including Poisson's ratio and Young's modulus, do not depend on the applied test method and the alteration in these properties in different joint positions provides values within a particular range [21]. These typical values of the mechanical properties of cartilage are summarized in Table 1. 
Table 1. Mechanical and biological properties of natural articular cartilage.

\begin{tabular}{|c|c|c|c|}
\hline Mechanical Property & Value & Test Method & Ref. \\
\hline Aggregate modulus (MPa) & $0.10-2.1$ & Confined compression & [22] \\
\hline Hydraulic permeability (m²/Pa.s) & $10^{-16}-10^{-15}$ & $\begin{array}{l}\text { Unconfined compression, } \\
\text { indentation }\end{array}$ & [22] \\
\hline Compressive Young's modulus (MPa) & $0.23-0.85$ & Unconfined compression & [22] \\
\hline Poisson's ratio & $0.05-0.30$ & Unconfined compression & [22] \\
\hline Tensile equilibrium modulus (MPa) & $5.0-12.0$ & Tensile stress relaxation & [22] \\
\hline Tensile Young's modulus (MPa) & $5.0-25.0$ & Tensile constant strain rate & [22] \\
\hline Tensile strength (MPa) & $0.7-25.0$ & Equilibrium shear & [22] \\
\hline Equilibrium shear modulus (MPa) & $0.05-0.40$ & Equilibrium shear & [22] \\
\hline Complex shear modulus (MPa) & $0.2-2.5$ & Dynamic shear & [22] \\
\hline Shear loss angle $\left(^{\circ}\right)$ & $10-15$ & Dynamic shear & [22] \\
\hline Biological property & \multicolumn{2}{|c|}{ Value } & Ref. \\
\hline Initial cell seeding & \multicolumn{2}{|c|}{$\geq 63$ million cells $/ \mathrm{mL}$} & [28] \\
\hline Osmolality & \multicolumn{2}{|c|}{ Physiological osmolality } & [29] \\
\hline Extracellular pH & \multicolumn{2}{|c|}{$7-8$} & [29] \\
\hline Pore size & \multicolumn{2}{|c|}{$2.5-6.5 \mathrm{~nm}$} & [29] \\
\hline Growth factors & \multicolumn{2}{|c|}{ PDGF, TGF- $\beta$, FGF, BMP, IGF } & [29] \\
\hline Mechanical loading (dynamic compression) & $2-10 \%$ strain or $0.5-$ & $\begin{array}{l}\text { at physiological frequency } \\
1.0 \mathrm{~Hz}\end{array}$ & [29] \\
\hline
\end{tabular}

The biological properties are another main factor that depends on the mechanical properties of the tissue constructs. For example, the high loss angle and plastic deformation occur in highly porous scaffolds (pore size $\geq 250 \mu \mathrm{m}$ ), although the storage modulus and aggregate modulus reduce in such scaffolds. Mainly, small pore size $(\leq 200 \mu \mathrm{m})$ causes lower aggregate modulus, propagation, and transition of nutrients and essential material; so, the suitable pore size and its propagation are essential for cell delivery and development of cartilage tissue [18]. Additionally, surface roughness and friction coefficient are two measurable tribological characteristics in both native and engineered articular cartilage. Native cartilage has a smooth and shiny surface with friction coefficients as low as 0.001 up to physiologically high pressures. However, human-made hydrogels are unable to match that of the native tissue $[20,30]$.

In addition, different scaffold materials are identified with distinct chondrocytes and mechanical and biological properties and could be utilized for controlling the mechanical properties of the engineered cartilage [31]. For example, the mechanical properties of poly(glycolic acid) (PGA) scaffolds are higher than the one with similar geometry made of poly(lactic acid) (PLA). Additionally, synthesized polyglyconate (PG) increases in poly(glycolic acid) scaffolds, whereas the synthesis of collagen type II enhances in collagenbased scaffolds [29]. Using an IPN scaffold helped to minimize the surface roughness of the scaffold by approximately $80 \%$.

\subsection{Damage and Treatment of Cartilage}

Articular cartilage defects are one of the major clinical challenges for orthopedic surgeons and typically begin due to trauma, unusual mechanical forces during an activity, aging, etc. Due to the limited ability of cartilage to self-regenerate, local lesions can lead to debilitating joint pain, functional impairment, and degenerative arthritis [24]. Articular cartilage incapability self-repair is attributed to its avascular nature of cartilage tissue, catabolism reflex to pathological inter-mediators, finite capability of progenitor cells migration, proliferation, and ECM production [32]. Nowadays, two main healing techniques 
are applied to treat cartilage injuries: surgical approaches and tissue engineering [33]. Depending on structural defects in the cartilage, an inevitable surgical intervention including osteotomy, autologous osteochondral graft transplantation, or total joint replacement is required. Chondroprogenitor cells from bone marrow or blood cannot easily reside within the injured area of the cartilage to repair it; therefore, the healing process begins within a few weeks. The tissue regenerated by the cartilage self-healing process is generally fibrotic and has poor mechanical and structural properties compared with the native healthy tissue [32,34]. The available surgical methods such as microfracture, mosaicplasty, transplantation of autologous chondrocyte transplantation and supportive matrix methods, and osteochondral allograft for healing of cartilage defects can alleviate pains and recover joint functions with great success [34]. However, cartilage regenerated by these methods does not recapitulate all the physiological specifications of natural cartilage and, thus, it does not last for a long period. For instance, the regenerated tissues usually contain collagen type I, which has undesirable chemical and mechanical properties [34].

Over the past two decades, tissue engineering has become one of the most popular methods to regenerate cartilage tissue and reconstruct it [16]. Two main procedures for the biofabrication process applied in CTE include cell-laden bio-inks for direct fabrication of structures and cell-free methods for scaffold constructions. However, in most cases, cartilage produced has a high fiber content and does not exhibit the ideal characteristics of hyaline cartilage because of the finite differentiation of stem cells. So, many research studies have been performed to improve mesenchymal cell-mediated osteochondral lesions and to increase the ability of stem cell differentiation, in order to create an organized chondral tissue with a cellular content that emulates ideal hyaline cartilage and ECM [2].

\section{Cartilage Tissue Engineering}

Since the 1990s, different biomaterials (natural and/or synthetic materials, chondrocytes, stem cells, growth factors) have been explored and examined in CTE for injection or scaffold implantation [35]. The main types of scaffolds are polymeric films, hydrogels, and fibrous scaffolds [36,37]. Among them, hydrogel scaffolds made of natural resources have become more popular due to their comparable structure and biological properties to native ECMs, which facilitate cell transplantation, proliferation, and differentiation [35,37].

The most important factors in the design of cartilage scaffolds are biocompatibility, biodegradability, cell differentiation and cartilage creation, stability, suitable mechanical properties and porosity, cell adhesion, and accretion with the adjoining native cartilage [16]. Because the cartilage mechanical properties may significantly change due to the age, joint donor site, and specimen orientation, various methods and procedures have been developed to improve the mechanical properties of an engineered cartilage. These include controlling the fiber geometry of the scaffolds, controlling the composition of ECM made by the chondrocytes, and the selection of different scaffold materials [21,36,38]. Scaffolds should have cell adhesion ligands, including epitopes for cells-surface interactions. This type of scaffolds can improve cell adhesion, cell differentiation, and integration into the surrounding native tissues. The ability to fill the irregular shape of the lesion and specific cell differentiation in damaged areas are other requirements for an ideal biomaterial scaffold used for delivering cells for cartilage healing [39]. Additionally, the mechanical properties of cartilage change with distance from the articular surface, maturation, degree of cartilage defect, and the capacity of compression and stress. Therefore, the desirable biomaterials for cartilage regeneration should be adjustable to mimic a range of the compression and tensile properties [40].

\subsection{Hydrogels for Cartilage Healing}

Hydrogels are 3D crosslinked hydrophilic networks of polymers or macromers that swell in an aqueous environment and create a platform for cells to proliferate and differentiate similar to a native ECM. The unique properties of hydrogels are mainly due to their high water content, specific structure, the ease of loading growth factors, and their 
mechanical properties [41]. Ideal biomaterials and specific production methods have main roles in improving desirable hydrogels that could be applied as CTE scaffolds [42].

A wide range of natural and synthetic biopolymers $[18,43]$ have been tested to produce hydrogels such as chitosan [44,45], collagen [46] or gelatin [47,48], alginate [49], hyaluronic acid [50,51], heparin [52,53], chondroitin sulfate [54], poly(ethylene glycol) (PEG) [55], and poly(vinyl alcohol) [56] (Figure 3). Table 2 summarizes the studies on the most popular biopolymers used to repair cartilage.

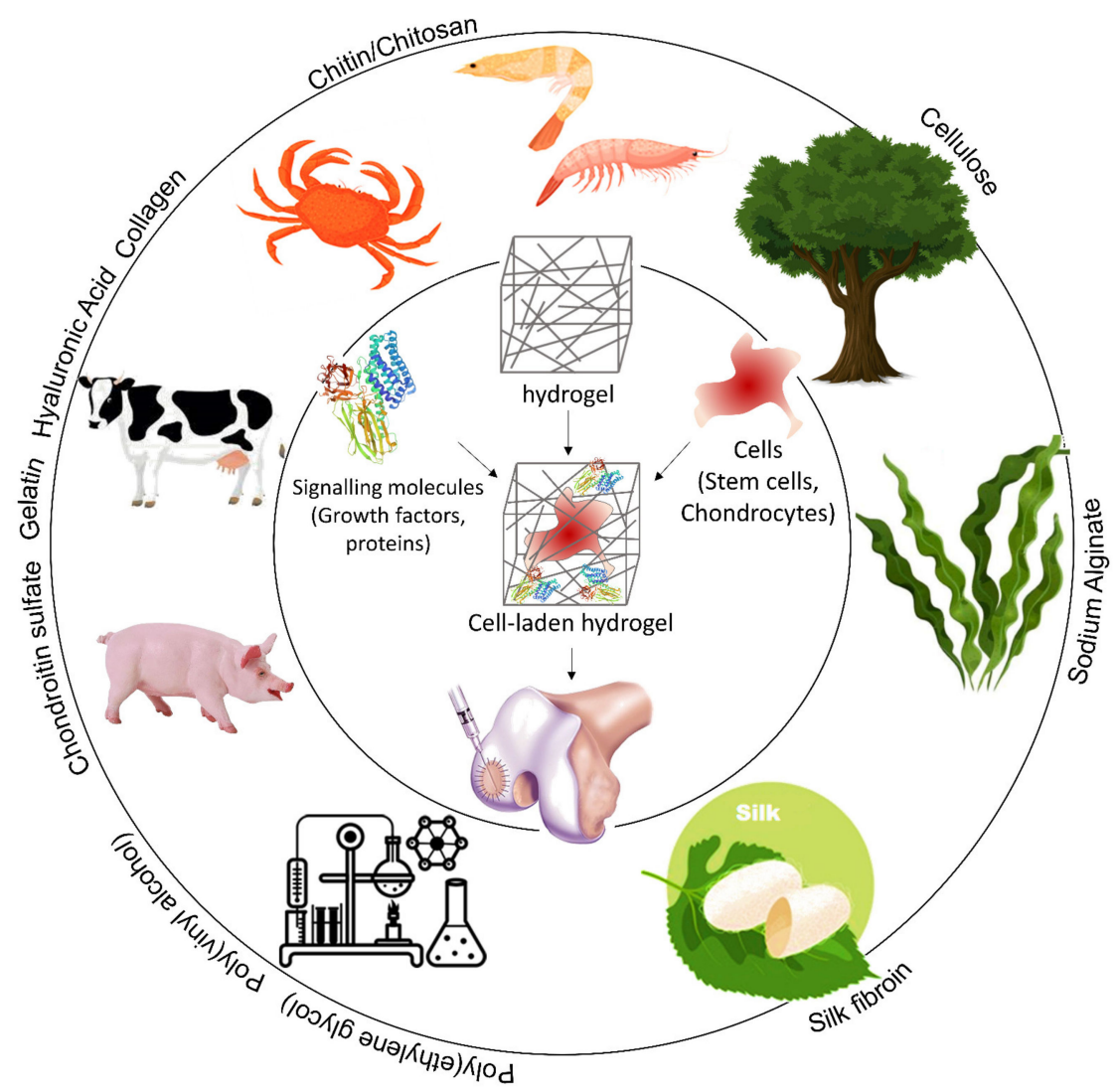

Figure 3. Schematic representation of different biopolymers used for CTE.

Hydrogels could be produced by physical and/or chemical processes. A schematic diagram of various methods of hydrogel production is represented in Figure 4. Physically prepared hydrogels are created via relatively weak intermolecular forces, but chemical methods of hydrogels preparation are typically created by covalent crosslinking [13].

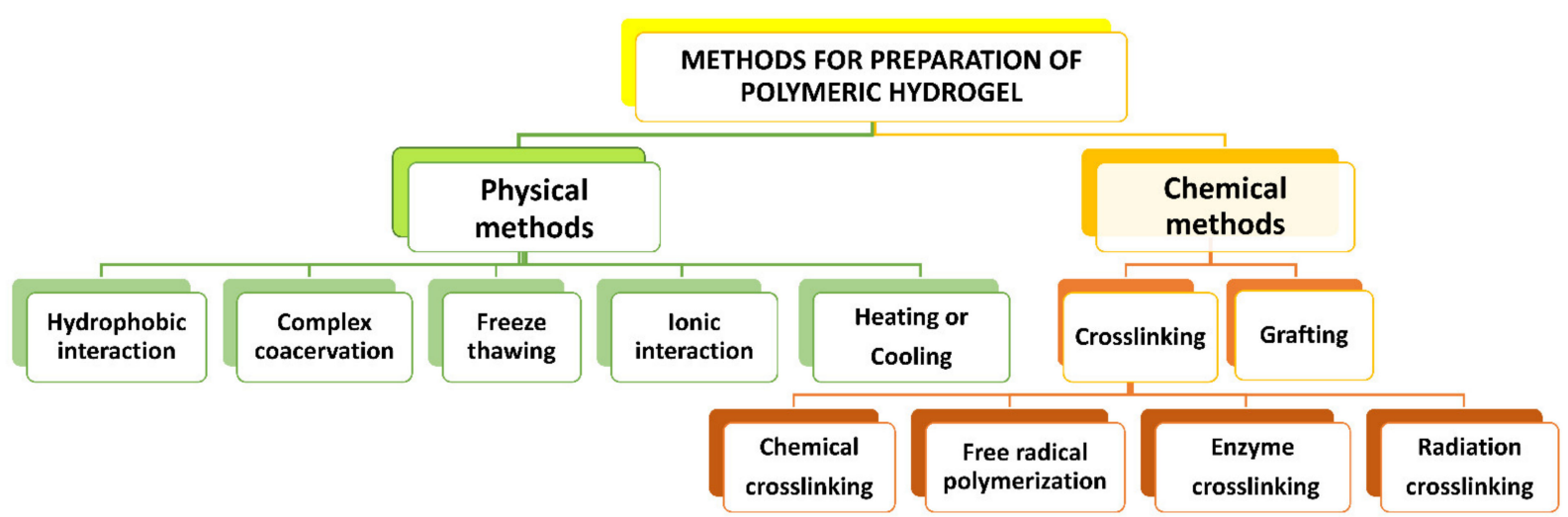

Figure 4. Various methods of hydrogel production. 
The viscoelasticity of hydrogels permits load transmission to chondrocytes [43]. Although different hydrogels produced by various procedures have been investigated in re-cent years, rarely have any integrated hydrogels been used in the regenerative medical profession. Hence, novel injectable hydrogels with improved physicochemical properties are required for cartilage regeneration in vivo [4,57].

Table 2. Summary of the last 10 years studies on cartilage regeneration via biopolymers.

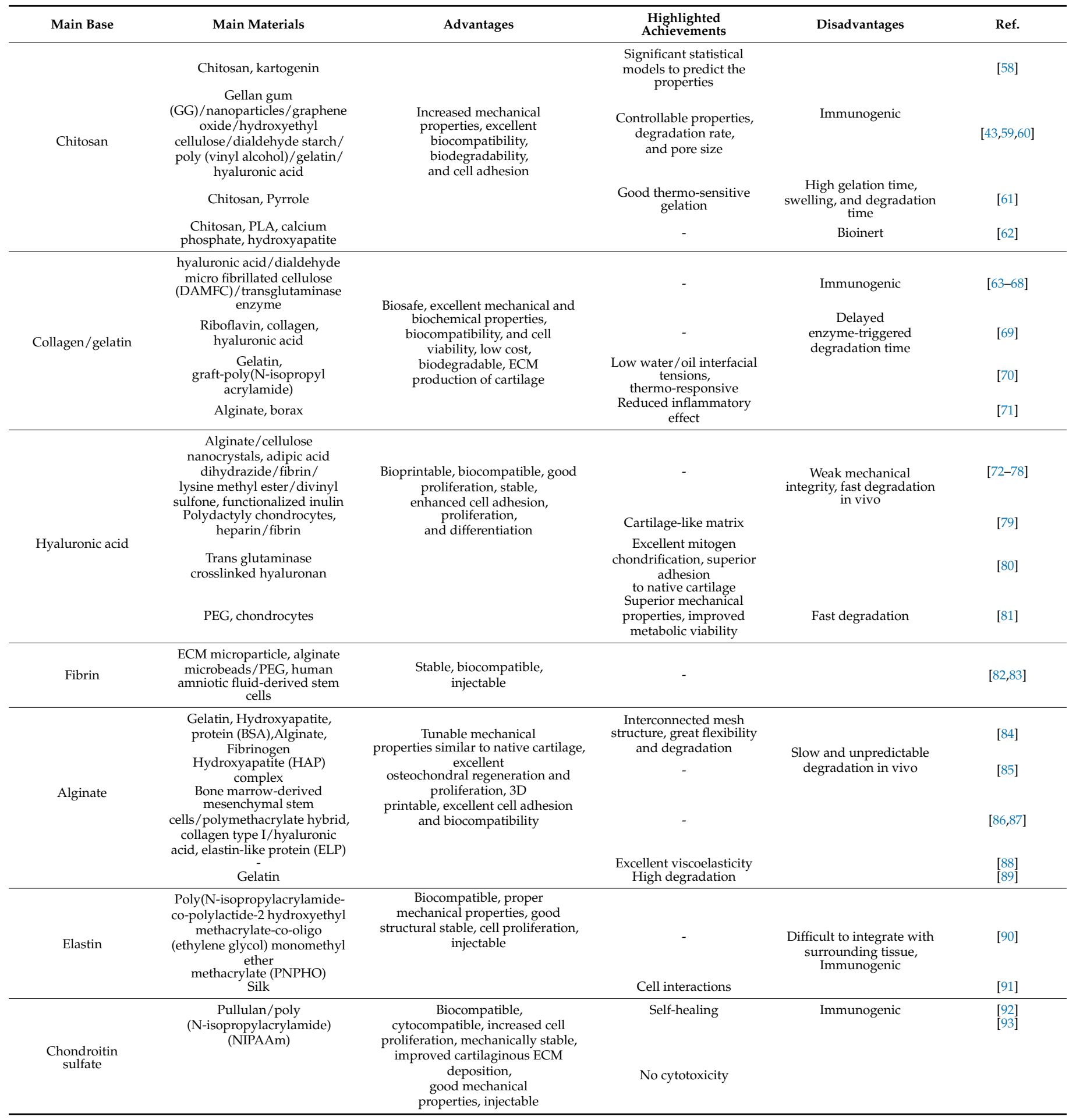




\subsection{Advanced Hydrogel for Cartilage Tissue Engineering}

Hydrogels based on single-polymer networks usually illustrate very poor mechanical properties compared with native cartilage [94]. For example, alginate is utilized as a single-component hydrogel because of its properties such as biocompatibility and ionic crosslinking using calcium ions. However, it is almost bioinert and has limited cell interaction and adhesion [95].

For improving the hydrogel mechanical properties to attain those of native cartilage, more complex systems of multiple polymers have been recently used. These systems not only display higher mechanical properties than single polymeric networks, but also illustrate better integration with living tissue environments [96]. Recent advances in the hydrogel are categorized into four main groups: multi-material hydrogels, supramolecular hydrogels, nanocomposites hydrogels, and interpenetrating network (IPNs) hydrogels [97].

Multi-material hydrogels are one of the studied bioinks to dominate the restrictions of single-component hydrogels. In multi-material hydrogels, different single polymeric components are crosslinked together chemically to improve the final characteristics of the composite construction [98]. Supramolecular polymers are another currently under study. Supramolecular (host-guest) interactions happen physically between two or more chemical portions via non-covalent bonds $[99,100]$. In a supramolecular interaction, a guest segment of the polymer chains is connected to a host segment by non-covalent interactions all over the hydrogel network [101,102].

Due to the reversibility of these interactions, formed polymer networks illustrate self-healing properties. The most popular self-healing polymers that involve in guesthost interactions are based on cyclodextrins, cucurbits. Under high tensions or forces, these non-covalent interactions are reversibly broken for damping network energy. The reversible bonds also develop shear-thinning properties that facilitate their application in CTE $[103,104]$. Jeong et al. modified hyaluronic acid (HA)-based hydrogels by $\beta$-cyclodextrin. Resulted hydrogels demonstrated remarkable shear-thinning, cell viability, adhesive strength, and desirable mechanical properties for CTE applications [105]. Until now, several hydrogel substances have been employed for stem cell therapy. Salati et al. reviewed the sources and superior properties of the agarose-based bio-materials with/without various types of signaling molecules and their functions in the keeping of cartilage homeostasis [18].

Nanocomposite hydrogels have been studied to tailor the properties of hydrogels. The addition of nanoparticles to the hydrogel matrix can considerably change physical and chemical specifications of the scaffold, such as compressive strength, elastic modulus, storage modulus, and degradation rate under physiological conditions [106]. Depending on nanoparticles applied to the hydrogel network, interesting functions and properties such as bioactivity, controlled drug delivery, and electrical conductivity are induced to the hydrogel matrix [107]. However, despite numerous advantages of nanocomposite hydrogels, few studies have investigated their applications for cartilage.

Mechanically tough hydrogels with limited deformation under cyclic loads are highly desirable in cartilage tissue regeneration [108]. When subjected to cyclic stress, conventional hydrogel bonding can break due to the lack of mechanical integrity. To improve the mechanical properties of hydrogel-based scaffolds, Piluso et al. developed a 3D nanocomposite hydrogel composed of gelatin and starch nanocrystals (SNCs). The incorporation of SNCs within the hydrogel matrix led to an increase in the compressive modulus from $2.0 \pm 0.1 \mathrm{kPa}$ to $3.1 \pm 0.1 \mathrm{kPa}$ when the SNCs content increased from 0 to $0.5 \mathrm{wt} \%$, compared with the hydrogel without SNCs [109]. Asadi et al. studied the role of various nanoparticles such as polymeric and silica nanoparticles in CTE $[107,110]$. They developed nanocomposite hydrogel scaffolds via combining gelatin and polycaprolactonepolyethylene glycol (PCL-PEG-PCL) nanoparticles which are loaded with transforming growth factor $\beta 1$ (TGF $\beta 1$ ) and evaluated their potential as scaffolds for cartilage tissue engineering. Their results demonstrated a higher Young's modulus of nanocomposite scaffold compared with the gelatin scaffold after the addition of PCL-PEG-PCL nanoparticles [110]. Bonhome-Espinosa et al. reported the fabrication of a novel magnetic 3D 
fibrin-agarose hydrogel using encapsulated magnetic nanoparticles and human native chondrocytes with the possibility of applying as articular cartilage tissues. The produced hydrogel showed excellent biocompatibility, viability, and proliferation in vitro [111]. The combination of nano-hydroxyapatite (n-HA) and magnetic nanoparticles $\left(\mathrm{Fe}_{2} \mathrm{O}_{3}\right)$ with poly(vinyl alcohol) (PVA) could also produce a magnetic nanocomposite hydrogel with tensile strength of $28.7 \mathrm{MPa}$ [112]. In another study, Nejadnik et al. investigated the addition of calcium phosphate nanoparticles to bisphosphonate-functionalized hyaluronic acid for knee cartilage tissue engineering. The resulting hydrogel illustrated superior properties including self-healing [113]. The development of injectable nanocomposite hydrogels with mechanical properties comparable with bovine cartilage was reported by Schlichting and co-workers. They fabricated a photopolymerizable PEG-1000 and Pluronic F-127 hydrogels embedded with calcium phosphate nanocrystals via an in-situ mineralization technique. Their nanocomposite hydrogels had compressive and shear modulus of $0.64 \pm 0.1 \mathrm{MPa}$ and 1.5-2 GPa, respectively, slightly higher than those of bovine cartilage $(0.35 \pm 0.1 \mathrm{MPa}$ and $0.7 \mathrm{GPa}$, respectively) [114].

Compared with multilateral composite hydrogels, interpenetrating networks (IPNs) are composed of independent polymer networks physically entangled to one another [115]. They are usually formed using different crosslinking methods and agents to solely crosslink one type of polymers within the network. Therefore, a network of independently crosslinked polymers are created that shows improved mechanical properties compared with their single-component network counterparts [116]. Generally, the primary polymeric network is made of flexible and elastic materials compared with the secondary network, which is stiffer and more brittle in relatively lower concentration $[115,116]$. Schipani et al. studied mechanically reinforced IPN hydrogels of alginate and gelatin methacryloyl (GelMA) reinforced by polycaprolactone (PCL) fibers. Motivated by the significant tension-compression nonlinearity of the collagen network in articular cartilage, they printed PCL networks to reinforce IPN hydrogels. This new composite hydrogel exhibited dynamic and equilibrium mechanical properties that approached or matched those of healthy articular cartilage [117]. Advanced hydrogels are summarized within the framework of different network types for cartilage tissue application in Table 3. Although a few research groups have reported the design of materials with predetermined properties and precise computational or mathematical models [118] to find their unique applications, the majority of researchers have simply combined new materials based on trial and error and characterized the properties of the final products [4]. These models provide us with useful tools to control hydrogel properties depending on the damaged cartilage area and its characteristics.

Stimuli-responsive hydrogels (SRHs) have gained great attention in drug delivery [119] and tissue engineering [120] due to their capability to undergo physical or chemical changes in response to external stimuli or small alterations in their environment. In contrast to the static hydrogel scaffolds, stimuli-responsive scaffolds have emerged as powerful platforms to dynamically respond to the cytocompatible stimuli, thus enabling on-demand manipulation of cell microenvironments. To induce such dynamic behaviors into the scaffolds, various physical (e.g., temperature [121,122], electrical or magnetic fields [123], wavelength or intensity of light [124-126], ultrasound [127]), chemical (e.g., pH [128,129], ionic strength [130], chemical triggers [131]), and biological (e.g., enzymes [132]) stimuli have been introduced. The extent of the responses to such triggers strongly depends on the nature and magnitude of a stimulus and the sensitivity of materials.

Temperature-responsive hydrogels that undergo physical sol-gel transitions can be easily implanted via minimally invasive operations without the need for external crosslinking agents [133]. However, the transition temperature, gelation time, and $\mathrm{pH}$ of polymer solutions should be precisely adjusted to meet clinical requirements and minimize detrimental effects on cell viability. N-isopropylacrylamides (NIPAAm), poloxamers, and different PEGbased polymers are common examples of temperature-responsive hydrogels [134]. Sá-Lima et al. explored the ability of poly(N-isopropyl acrylamide)-g-methylcellulose (PNIPAAm$\mathrm{g}-\mathrm{MC}$ ) hydrogels (with lower critical solution temperature of $\sim 32{ }^{\circ} \mathrm{C}$ ) in supporting cell 
encapsulation and GAGs production, required for cartilage regeneration [135]. Park et al. introduced an injectable thermo-sensitive chitosan-pluronic hydrogel as a potential candidate for CTE [136]. This hydrogel demonstrated a transition temperature of $\sim 25^{\circ} \mathrm{C}$ and could support the proliferation of bovine chondrocytes and the synthesis of glycosaminoglycan for 28 days. Recently, Abbadessa et al. synthesized methacrylated pHPMA-lac-PEG hydrogels (a thermo-responsive triblock copolymer) for cartilage 3D bioprinting [137]. It was found that the incorporation of polysaccharides (methacrylated chondroitin sulfate (CS-MA) or methacrylated hyaluronic acid (HA-MA)) could improve the stability and printability as well as the mechanical properties of the hydrogel-based constructs.

The $\mathrm{pH}$-responsive hydrogels contain acidic or basic functional groups with proton exchange capability, depending on the $\mathrm{pH}$ of the surrounding environment. Strehin et al. synthesized a pH-responsive chondroitin sulfate (CS) - PEG adhesive hydrogel with potential applications in regenerative medicine, including cartilage repair [138]. It was found that changes in the initial $\mathrm{pH}$ of the precursor solutions could impact the stiffness, swelling properties, and kinetics of gelation of the final hydrogel products. In another study, Halacheva et al. developed $\mathrm{pH}$-sensitive hydrogels from poly(methacrylic acid)containing crosslinked particles with high porosity, elasticity, and ductility [139]. The enhanced mechanical properties of the produced hydrogels made them a suitable candidate for regenerative medicine. Sá-Lima et al. designed $\mathrm{pH}$-sensitive hydrogels based on chitosan- $\beta$-glycerophosphate-starch with the ability to induce chondrogenic differentiation of adipose-derived stromal cells (ADSC) for CTE [140]. Despite considerable progress in the development of $\mathrm{pH}$-responsive hydrogels for cartilage regeneration, it is still difficult to clinically predict the $\mathrm{pH}$ at the diseased site, which may cause undesired tissue response.

Light-sensitive hydrogels can also be applied for CTE. Levett et al. prepared photocrosslinkable hydrogels based on gelatin methacrylamide that enhanced chondrogenic differentiation and improved mechanical properties of the regenerated cartilage [141]. Giammanco et al. developed photo-responsive hydrogels composed of alginate-acrylamide hybrid gels and ferric ions [142]. The physicochemical properties of these hydrogels could be modulated using visible light irradiation. While better spatial and temporal control over precursor gelation can be achieved via photo-crosslinking processes, their in vivo applications can be restricted due to the potential toxicity of photo-initiators at an elevated temperature over a prolonged irradiation period.

Chemical bonds formation and cleavage by enzymes can also be utilized for hydrogels formation. Skaalure et al. synthesized aggrecanase-sensitive hydrogels based on photoclickable thiol-ene PEG that contains a CRDTEGE-ARGSVIDRC peptide, derived from the aggrecanase-cleavable site in aggrecan [132]. The bovine chondrocytes encapsulated within this hydrogel produced a connected matrix rich in aggrecan and collagen II, but not collagens I and X. In contrast, the matrix deposition in the non-degradable hydrogels (i.e., control groups) consist of aggrecan and collagens I, II, and X, indicative of hypertrophic cartilage. Jin et al. prepared injectable chitosan-graft-glycolic acid (GA) and phloretic acid (PA) (CH-GA/PA) hydrogels enzymatically crosslinked via horseradish peroxidase (HRP) and hydrogen peroxide $\left(\mathrm{H}_{2} \mathrm{O}_{2}\right)$ [143]. They also synthesized injectable hydrogels using hyaluronic acid-dextran-tyramine conjugates with potential applications for CTE [144]. The hydrogels were formed via enzymatic crosslinking of tyramine residues in the presence of HRP. Nevertheless, the high concentration of $\mathrm{H}_{2} \mathrm{O}_{2}$ during injection may cause cytotoxicity in these hydrogels in vivo [145]. For the development of smart scaffolds that can respond to various stimuli, we direct readers to an excellent published review in the literature [119]. 
Table 3. Summary of advanced hydrogel in cartilage tissue engineering.

\begin{tabular}{|c|c|c|c|c|}
\hline $\begin{array}{c}\text { Advanced } \\
\text { Hydrogel Type }\end{array}$ & Main Materials & Advantages & Disadvantages & Ref. \\
\hline \multirow{3}{*}{ Multi materials } & $\begin{array}{c}\text { Chondrocyte-laden GelMA, } \\
\text { PCL }\end{array}$ & $\begin{array}{l}\text { Porous structure, cell } \\
\text { proliferation, excellent } \\
\text { mechanical and } \\
\text { thermo-reversible } \\
\text { properties, printable }\end{array}$ & $\begin{array}{l}\text { Long-time UV exposure } \\
\text { and low cell viability }\end{array}$ & [146] \\
\hline & PCL, Pluronic F-127 & $\begin{array}{l}\text { Biocompatible, biodegradable, } \\
\text { finite antigenicity }\end{array}$ & $\begin{array}{l}\text { Immune response and } \\
\text { therapeutic efficacy } \\
\text { have not determined }\end{array}$ & [147] \\
\hline & $\begin{array}{l}\text { Poly(vinyl alcohol), } \\
\text { poly(E-caprolactone), } \\
\text { Gelatin } \\
\text { methacrylamide/Gellan } \\
\text { gum, Alginate }\end{array}$ & $\begin{array}{l}\text { Great differentiation, ability to } \\
\text { produce complex structure and } \\
\text { support components }\end{array}$ & Low shape fidelity & [98] \\
\hline \multirow{10}{*}{ IPN } & $\begin{array}{l}\text { Polycaprolactone, Poly } \\
\text { (acrylic acid), Cellulosic } \\
\text { nano-whisker, } \\
\text { Acrylic-urethane } \\
\text { cross-linker }\end{array}$ & $\begin{array}{c}\text { Improved the mechanical } \\
\text { properties, water } \\
\text { absorption of about } 30 \%, \\
\text { excellent hydrophilic property }\end{array}$ & $\begin{array}{c}\text { Need to optimization } \\
\text { of physicochemical } \\
\text { surface } \\
\text { conditions for cell } \\
\text { adhesion } \\
\text { and proliferation }\end{array}$ & [148] \\
\hline & $\begin{array}{l}\text { Carboxymethyl dextran, } \\
\text { Amino dextran }\end{array}$ & $\begin{array}{c}\text { Excellent mechanical stable, } \\
\text { adhesion, and spreading } \\
\text { behavior of fibroblast cells, } \\
\text { biodegradable and } \\
\text { biocompatible }\end{array}$ & $\begin{array}{l}\text { Immune responses have } \\
\text { not been determined }\end{array}$ & [149] \\
\hline & $\begin{array}{l}\text { Hydroxyapatite particles, } \\
\text { Alginate }\end{array}$ & $\begin{array}{l}\text { Proper osteochondral healing, } \\
\text { suitable } \\
\text { compressive modulus and } \\
\text { swelling property, high porosity, } \\
\text { uniform pores }\end{array}$ & $\begin{array}{l}\text { Using of poor } \\
\text { supramolecular } \\
\text { gelation agent }\end{array}$ & [150] \\
\hline & $\begin{array}{c}\text { Conjugated dextran with } \\
\text { 2-naphthylacetic, HA, } \\
\text { B-cyclodextrin }\end{array}$ & $\begin{array}{l}\text { Excellent resilience, good } \\
\text { biocompatibility }\end{array}$ & $\mathrm{N} / \mathrm{A}$ & [151] \\
\hline & $\begin{array}{l}\text { Gelatin, Alginate } \\
\text { polyacrylamide }\end{array}$ & $\begin{array}{l}\text { Enhanced mechanical } \\
\text { properties, excellent cell } \\
\text { proliferation, finite cytotoxicity, } \\
\text { chondrogenic gene expression, } \\
\text { and structural stability, great } \\
\text { porosity in long-term }\end{array}$ & $\begin{array}{l}\text { Uncontrollable porosity, } \\
\text { Formation of a thin } \\
\text { superficial layer that } \\
\text { does not allow cell } \\
\text { penetration }\end{array}$ & [152] \\
\hline & $\begin{array}{c}\text { Ethylene } \\
\text { diamine-functionalized HA, } \\
\text { Divinyl sulfone-inulin }\end{array}$ & $\begin{array}{l}\text { Biodegradable, FDA-approved, } \\
\text { good mechanical properties }\end{array}$ & Low cell viability & [78] \\
\hline & $\begin{array}{l}\text { Low-molecular-weight PVA, } \\
\text { High molecular weight HA }\end{array}$ & $\begin{array}{c}\text { Biocompatible, excellent } \\
\text { swelling properties and cell } \\
\text { viability }\end{array}$ & $\begin{array}{l}\text { Fast gelation in room } \\
\text { temperature }\end{array}$ & [153] \\
\hline & $\begin{array}{l}\text { Poly(ethylene glycol), } \\
\text { Low-molecular weight HA }\end{array}$ & $\begin{array}{l}\text { Excellent solubility in GAG } \\
\text { deposition during structure } \\
\text { maturation, support } \\
\text { of collagen biosynthesis }\end{array}$ & $\begin{array}{l}\text { Low enzyme } \\
\text { degradation }\end{array}$ & [154] \\
\hline & Methacrylated HA, Fibrin & $\begin{array}{l}\text { Biocompatible, Support of } \\
\text { differentiation }\end{array}$ & $\begin{array}{l}\text { Unstable and unsuitable } \\
\text { mechanical properties } \\
\text { in low concentration }\end{array}$ & [155] \\
\hline & $\begin{array}{l}\text { Methacrylated chondroitin } \\
\text { sulfate, } \\
\text { Agarose-poly(ethylene } \\
\text { glycol) diacrylate }\end{array}$ & $\begin{array}{l}\text { Enhanced collagen biosynthesis } \\
\text { and GAGs in the cell-matrix, } \\
\text { low cost }\end{array}$ & Low cell viability & [156] \\
\hline
\end{tabular}


Table 3. Cont.

\begin{tabular}{|c|c|c|c|c|}
\hline $\begin{array}{c}\text { Advanced } \\
\text { Hydrogel Type }\end{array}$ & Main Materials & Advantages & Disadvantages & Ref. \\
\hline \multirow{2}{*}{ Supramolecular } & $\begin{array}{c}\text { Adamantane-functionalized } \\
\text { HA, monoacrylated } \\
\beta \text {-cyclodextrin }\end{array}$ & $\begin{array}{l}\text { Great drying and re-swelling } \\
\text { without changes in water } \\
\text { content or shape, excellent } \\
\text { collagen } \\
\text { deposition, suitable biophysical } \\
\text { properties, rapid stress } \\
\text { relaxation self-healing }\end{array}$ & $\mathrm{N} / \mathrm{A}$ & [157] \\
\hline & $\begin{array}{l}\text { Cucurbituril, } \\
\text { diaminohexane }\end{array}$ & $\begin{array}{l}\text { Controlled dexamethasone } \\
\text { release, enhanced cell } \\
\text { proliferation, GAG synthesis, } \\
\text { and chondrogenic gene } \\
\text { expression, in vivo neocartilage } \\
\text { production }\end{array}$ & $\mathrm{N} / \mathrm{A}$ & [158] \\
\hline \multirow{7}{*}{ Nanomaterials } & $\begin{array}{c}\text { Alginate, Poly(acrylamide) } \\
\text { hydrogel, } \\
\text { poly(lactide-co-glycolide) } \\
\text { (PLGA) nanoparticles }\end{array}$ & $\begin{array}{c}\text { Great viscoelasticity, } \\
\text { biodegradable, } \\
\text { biocompatible and protein } \\
\text { absorber, excellent cell } \\
\text { proliferation and mechanical } \\
\text { strength, stable }\end{array}$ & $\mathrm{N} / \mathrm{A}$ & [159] \\
\hline & $\begin{array}{l}\text { Poly(vinyl alcohol), } \\
\text { Graphene oxide }\end{array}$ & $\begin{array}{c}\text { Great bio-mechanical and } \\
\text { bio-friction properties, excellent } \\
\text { shear-thinning, printability, } \\
\text { and printing accuracy, proper } \\
\text { compressive and tribological } \\
\text { properties }\end{array}$ & Unsuitable pore size & [160] \\
\hline & $\begin{array}{c}\text { Nano hydroxyapatite, } \\
\text { Poly(vinyl alcohol), } \\
\text { Poly(lactic-co-glycolic acid) }\end{array}$ & $\begin{array}{l}\text { Biocompatible, practicable, } \\
\text { excellent mechanical properties, } \\
\text { sensitive to compressive stress, } \\
\text { suitable chondrocyte adhesion } \\
\text { and proliferation }\end{array}$ & $\mathrm{N} / \mathrm{A}$ & [161] \\
\hline & $\begin{array}{c}\text { Poly(vinyl alcohol), } \\
\text { Nano-hydroxyapatite, } \\
\text { magnetic Nanoparticles } \\
\left(\mathrm{Fe}_{2} \mathrm{O}_{2}\right)\end{array}$ & $\begin{array}{c}\text { Proper mechanical properties, } \\
\text { great mesenchymal stem cells } \\
\text { growth }\end{array}$ & Variable crystallinity & [112] \\
\hline & $\begin{array}{c}\text { Hydroxypropyl } \\
\text { methylcellulose, Laponites }\end{array}$ & $\begin{array}{c}\text { Excellent mechanical properties, } \\
\text { oxygen } \\
\text { diffusion, and cell expression }\end{array}$ & $\begin{array}{l}\text { Some toxicity, decreased } \\
\text { cell density }\end{array}$ & [162] \\
\hline & PEG, Laponite particles & $\begin{array}{l}\text { Good elastic modulus, } \\
\text { biocompatible, excellent } \\
\text { mechanical properties }\end{array}$ & Low cell viability & [163] \\
\hline & $\begin{array}{c}\text { Silk fibers, } \\
\text { Chitosan/Glycerophosphate }\end{array}$ & $\begin{array}{l}\text { Excellent mechanical properties, } \\
\text { GAG, } \\
\text { and collagen type II expression }\end{array}$ & $\begin{array}{l}\text { Unsuitable biological } \\
\text { properties, toxic } \\
\text { gelation agent }\end{array}$ & [164] \\
\hline
\end{tabular}

\section{Self-Healing Hydrogel in Cartilage Tissue Engineering}

Recently, self-healing soft systems with large deformation capabilities have been developed using multiple crosslinking mechanisms. These materials have attracted significant attention due to their extensive applications in electronics, coatings, and biomedical prosthetics [12]. Self-healing enables materials to repair themselves and restore their morphology and mechanical properties after defects. This ability not only maintains the longevity of a system, but also enhances the mechanical stability and prevents sudden or permanent failure of such materials in sensitive applications [165].

One of the basic self-healing techniques for the repair of polymer network defects is the increase of temperature. Thermoplastics, i.e., polymers that can be melted and re-cast almost indefinitely, benefit from a simple self-healing mechanism activated upon heating to a temperature above their melting points [166]. However, they usually show low stiffness and thermal stability which limit their applications where mechanically robust structures are needed. Therefore, self-healing research has mainly focused on thermosetting polymers, i.e., polymers that are irreversibly hardened by heat [167]. In thermosets, however, the intrinsic chain mobility within the polymer network is slow or negligible compared with thermoplastics. While heating is a simple method of self-healing, the restrictions excreted by the physicochemical properties of new materials have made an 
inevitable need for the development of new techniques to accelerate the self-healing process. Self-healing approaches can be classified into (i) intrinsic healing, due to an inherent ability of materials to self-heal, triggered either by a damage or in combination with an external stimulus and (ii) extrinsic healing, based on the release of the healing agents (e.g., liquid agents such as catalysts, monomers, hardeners containing microcapsules and hollow fibers embedment), pre-embedded into the (polymeric) matrix, upon damage [168]. In general, both intrinsic and extrinsic processes can be accomplished via physical self-healing by chain entanglements and chemical self-healing by the recovery of chemical bonds (e.g., hydrogen bonds, covalent bonds, etc.) [169], shown in Figure 5.

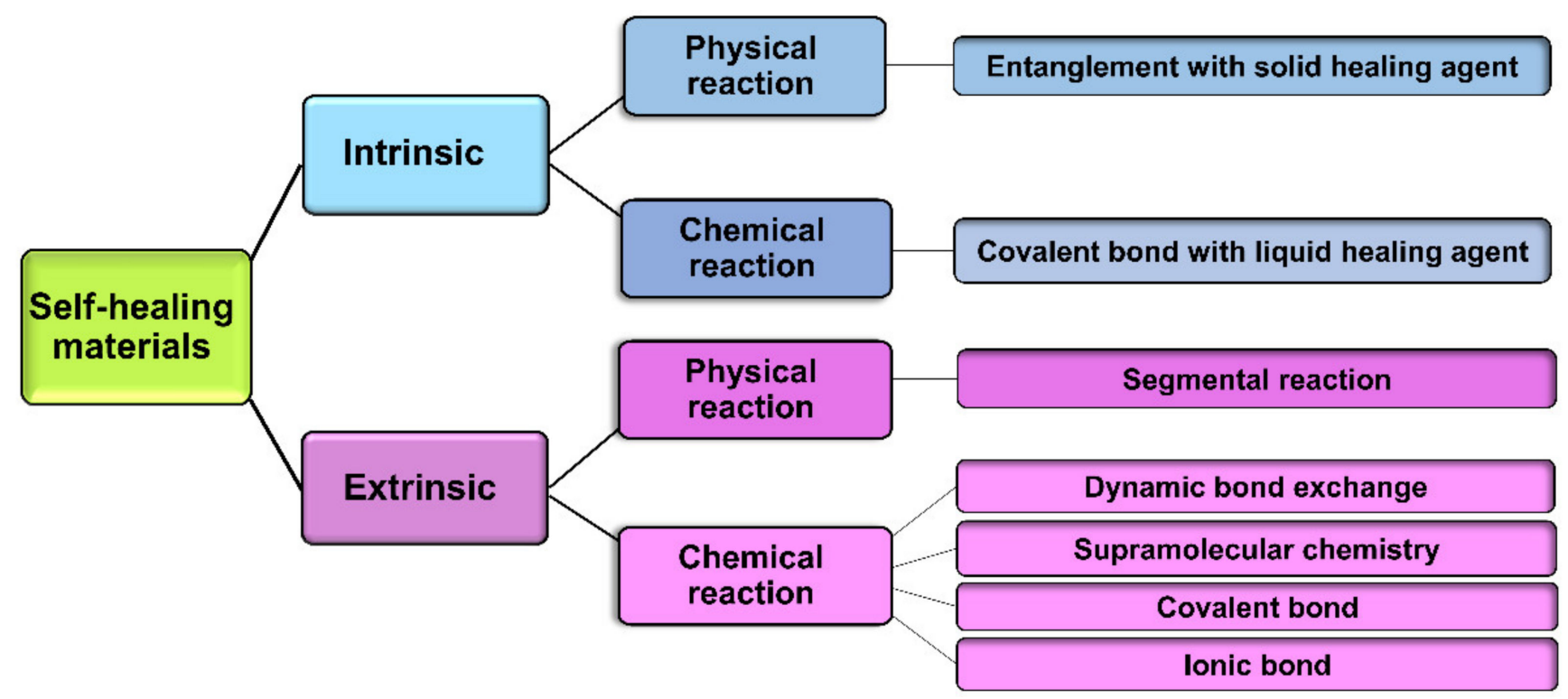

Figure 5. Schematic classification of self-healing schemes.

Self-healing in hydrogels are prepared via dynamic covalent reactions (chemical crosslinking) and/or non-covalent reactions (physical crosslinking) [23] shown in Figure 6. In covalent reactions, the re-use of polymerization conditions or the utilization of an external stimulus (e.g., heat [148], $\mathrm{pH}$ [170], UV, visible light [171]) is necessary for the completion of the healing process. In contrast, autonomous self-healing generally occurs in materials without using an external stimulus and leads to partial or full recovery of their physicochemical characteristics (e.g., mechanical properties). Non-covalent interactions commonly employ an individual or a combination of bonding mechanisms such as ionic bonding [172], hydrogen-bonding [173,174], supramolecular interactions [101], hydrophobic bonding [175], and molecular diffusion and chain entanglement [169]. 
(1)

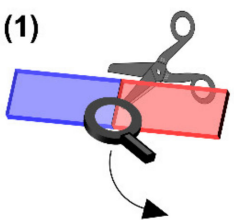

(2)

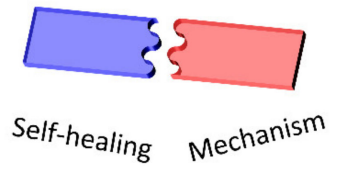

(3)

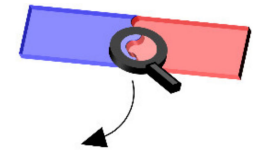

Covalent interactions

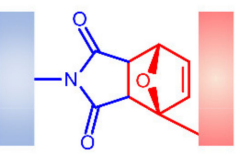

Diels-Alder reactions

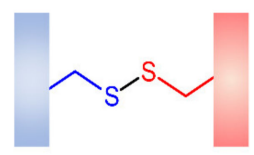

Disulfide bonds

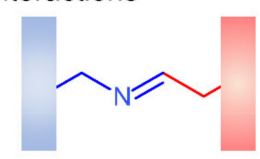

Imine bonds

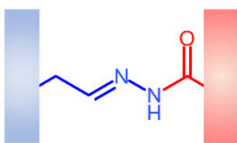

Acylhydrazone bonds<smiles>CSC(=S)SC</smiles>

Reversible radical reactions
Non-covalent interactions

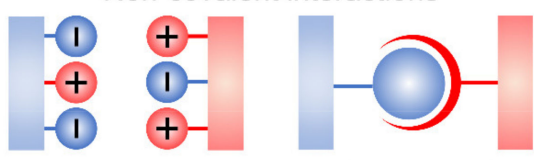

Ionic bonds

Host-guest Interactions

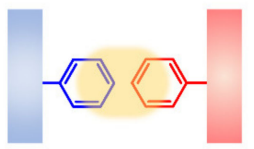

$\pi-\pi$ interactions

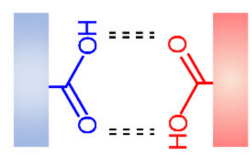

Hydrogen bonds

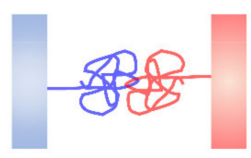

Hydrophobic interactions

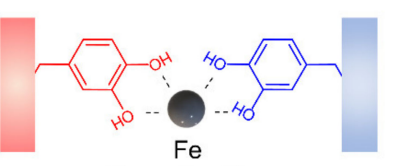

Coordination

bonds

Figure 6. Main self-healing mechanisms and polymer behavior in hydrogels. (1). Damage occurrence, (2). Self-healing process, and (3). Healed hydrogel.

\subsection{Materials}

Self-healing hydrogels made from either natural or synthetic polymers can be obtained by incorporating functional groups mentioned above in the polymer backbones via various non-hazardous and non-toxic chemical modifications. Natural hydrogels used for self-healing hydrogels include plant-derived hydrogels (e.g., polysaccharide-based alginate, carboxymethyl cellulose, cellulose, and agarose) and animal-derived hydrogels (hyaluronic acid, gelatin, chitosan, collagen, and fibrin). Synthetic hydrogels are based on polymers such as poly (ethylene glycol), poly (acrylic acid), poly (vinyl alcohol), and polyacrylamide $[168,176]$. It is possible to use a combination of a synthetic and natural polymer to produce novel hydrogels with remarkable positive properties of both components [168]. Roh et al. combined polysaccharide-based hydrogels with alginate to reinforce self-healing and properties such as stability, viscoelasticity, and printability by dual crosslinking for CTE application [177]. Wang et al. produced a dual responsive hydrogel based on oxidized sodium alginate (OSA) and hydrazide-modified poly(ethyleneglycol) (PEG-DTP) with injectability and self-healing properties. OSA has weak properties at low $\mathrm{PH}$. However, PEG-DTP efficiently enhanced the flexibility, self-healing, mechanical properties, and hydrophilicity of OSA due to the reversibility of its dynamic acylhydrazone connections. The resulting hydrogels illustrated self-healing of approximately 100\% after damage [178]. In another study, Yu and coworkers introduced a multifunctional hydrogel of hyaluronic acid, furylamine (furan), and adipic dihydrazide. Combination of Diels-Alder click reaction and acylhydrazone bond enhanced integrity and mechanical performance of this hydrogel in a 
biological environment, although the dynamic covalent bond of acylhydrazone created an excellent autonomous self-healing property and cell-adhesion for CTE applications [179]. However, other self-healing hydrogels based on peptides, mussel-inspired proteins, conductive polymers, and zwitterionic polymers have also obtained attention in recent years; however, they are not suitable for cartilage tissue engineering $[167,169]$.

\subsection{Mechanisms of Self-Healing}

Generally, intrinsic self-healing hydrogels are preferred in CTE applications due to their superior advantages in the restoration of their functions without adding new chemicals. Re-crosslinking damaged scaffolds via chemical reactions of different functional groups or physical interactions is the main objective in all intrinsic self-healing processes (these mechanisms have been discussed in detail elsewhere [180]). The intrinsic selfhealing is dependent on reversible crosslinking. The type and strength of bonds (used as crosslinkers) define the degree of self-healing, durability, and the mechanical properties of repaired hydrogels. Thus, they are the main factors in designing hydrogels with specific applications. For example, hydrogels made of physical crosslinking via hydrogen bonds are mechanically weaker than covalently crosslinked hydrogels of the same materials [180-182]. The bonding energy of hydrogen bonds is typically in the range of 5 to $30 \mathrm{~kJ} \mathrm{~mol}^{-1}$, around 10 times weaker than that of covalent bonds $\left(\approx 345 \mathrm{~kJ} \mathrm{~mol}^{-1}\right.$ for C-C bonds). The energy of the hydrogen bonds mostly depends on the negative charge of acceptor atoms (i.e., $\mathrm{O}$, $\mathrm{N}, \mathrm{F}$ ) and, therefore, it varies significantly with the electronegativity of acceptor atoms and $\mathrm{pH}$ of the solution in which the interactions occur. The strongest hydrogen bonds are associated with hydroxyl $(-\mathrm{OH})$ or amide $(-\mathrm{NH})$ groups while the weakest are those that incorporate fluorine.

Hydrophobic interactions play an essential role in biological systems for shape changing of proteins in water-rich environments and membrane formation. These interactions are slightly stronger than hydrogen bonds and can be easily modulated through altering the shape and the balance of hydrophobic and hydrophilic moieties in a system [183]. In intrinsic self-healing hydrogels, the presence of hydrophobic interactions leads to the re-arrangement of hydrophobic blocks to reduce or eliminate contacts with water molecules. Jeon et al. introduced novel hierarchical systems of non-covalent crosslinks with excellent stretchability and damage recovery created by incorporating amphiphilic polymers (UPyHCBA with an acrylic head, a hydrophobic alkyl spacer, and a 2-ureido4-pyrimidone (UPy) tail) and surfactants (sodium dodecyl sulfate) into polyacrylamide hydrogels (Figure 7a) [105]. The obtained hydrogels were able to stretch 100 times their initial length and to intrinsically self-heal within $\sim 30 \mathrm{~s}$. Using reversible hydrophobic interactions, Meng et al. fabricated silk fibroin-based hydrophobic-association hydrogels incorporated into an alginate ionic network (Figure 7b) [184]. This new system demonstrated excellent biocompatibility, mechanical properties, and intrinsic self-healing behavior without applying external energy at room temperature.

Due to the limited research on the suitable dynamic chain mobility of supramolecular and component interactions, the production of self-healing materials with versatile mechanical properties still remains a challenge [185], impeding their real-world applications that require mechanical integrity. Recent advances in supramolecular chemistry have accelerated the development of an increasing number of biologically inspired hydrogels $[186,187]$. Biopolymers physically crosslinked via host-guest interactions in supramolecular hydrogels have shown great potential for the development of minimally invasive therapeutics [188]. Most of these hydrogels demonstrate shear-thinning behavior under shear stress and recovery (i.e., self-healing) when the shear force is removed. However, these systems generally rely on nonspecific interactions, leading to protracted recovery times (from minutes to hours) following the shear stress removal [189]. This limits the efficacy of injectable hydrogels in the immobilization of material components or encapsulated cargos (e.g., cells, growth factors, etc.) at a target site. To overcome this problem, host-guest interactions based on non-covalent bonding of a macrocyclic host (e.g., cyclodextrin (CD)) and a comple- 
mentary guest molecule (e.g., adamantane) have been introduced (Figure 8a,b) [190-193]. Generally, host-guest hydrogels are mechanically weak [194,195]. This issue significantly limits their widespread applications in tissue engineering, particularly in load-bearing tissues such as cartilage. Recently, Jeong and co-workers reported injectable hydrogels based on $\beta$-cyclodextrin-modified hyaluronate and adamantane-modified HA, encapsulating mesenchymal stem cells (MSCs) for CTE applications. These hydrogels demonstrated remarkable mechanical characteristics including shear-thinning and self-healing with high cell viability [105]. The therapeutic efficacy of the HA hydrogels/MSCs for cartilage tissue regeneration was evaluated in vivo (Figure 8c), where the hydrogels/MSCs confirmed better macroscopic neocartilage formation covering the entire defect area compared with control groups. He et al. introduced a highly stretchable and tough alginate-based cyclodextrin/azo-polyacrylamide composite with self-healing properties via light irradiation [196] (Figure 8d). The azobenzene group used in the chemical structure of these hydrogels is a light-responsive group that experiences a reversible transformation between a cis structure (under light irradiation) and a trans structure (in the absence of light). Therefore, host-guest interactions between Azo derivatives and CD derivatives under the dark condition yielded hydrogels with the tensile strength of $0.06 \mathrm{MPa}$ at $1819 \%$ strain, where the presence of calcium ions crosslinking alginate chains increased the tensile strength but reduced the elongation of hydrogels. While many self-healing hydrogel platforms currently exist, Table 4 highlights the most promising systems for cartilage tissue engineering.

a)

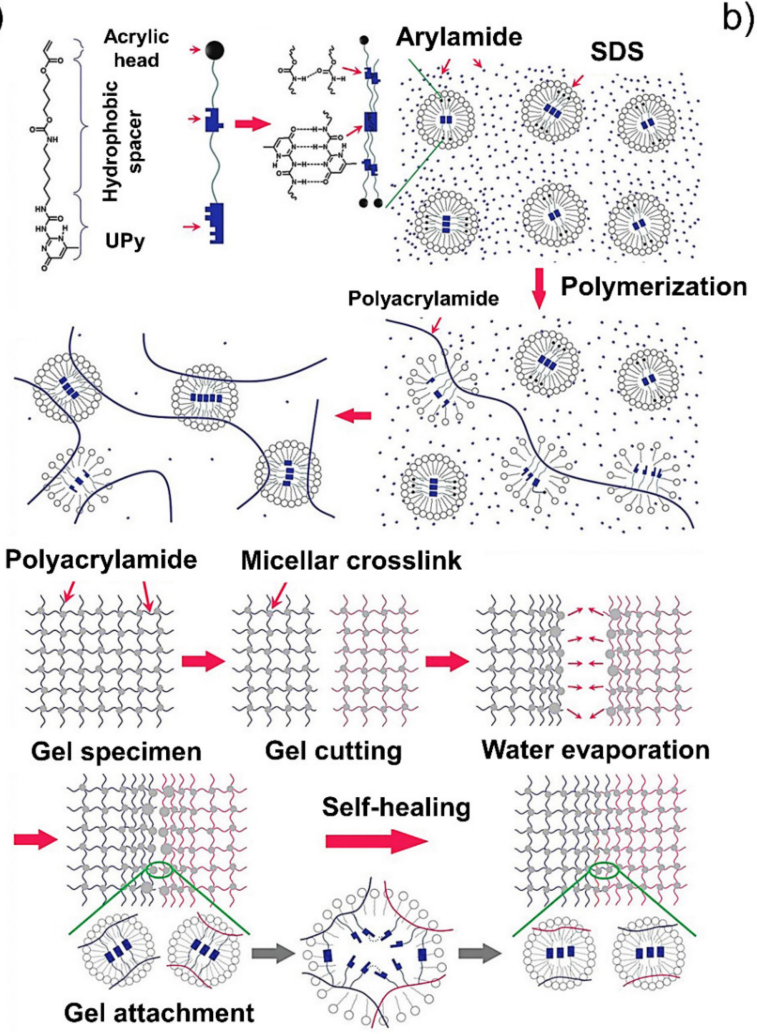

b)
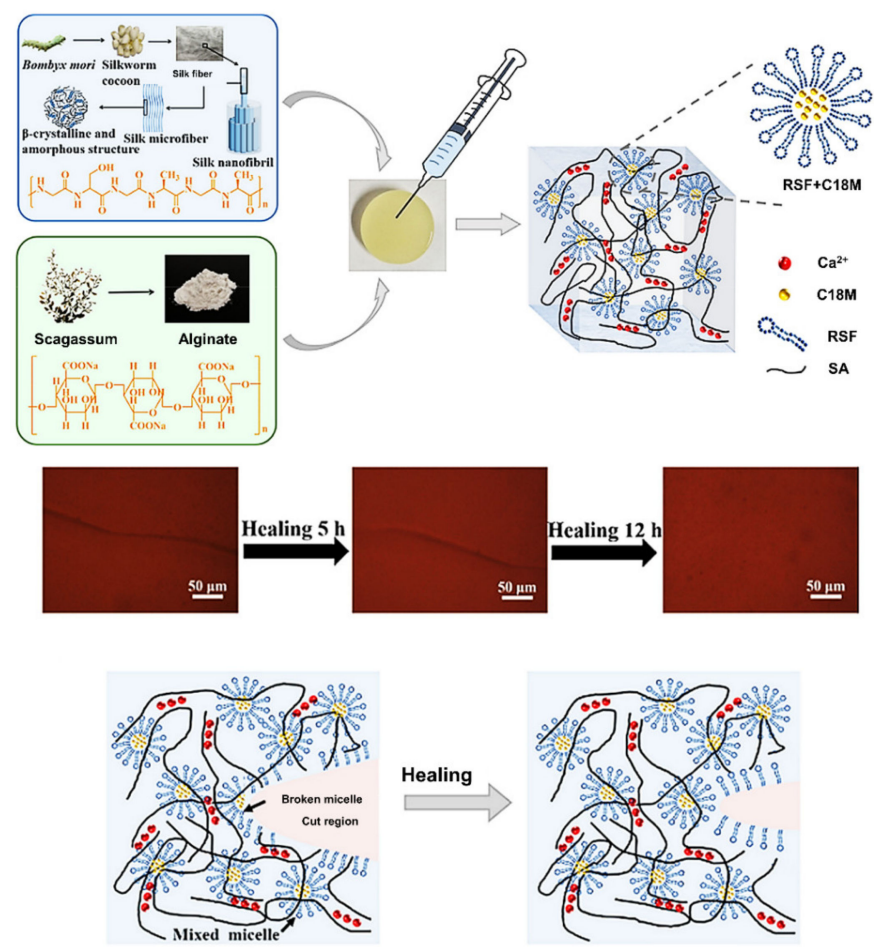

Figure 7. (a) Schematic illustration of the micellar copolymerization of the UPyHCBA and acrylamide. The self-healing mechanism (i.e., hydrophobic interactions) of the micellar copolymerization hydrogels [183]. (b) Schematic illustration of the preparation process of silk fibroin-based hydrophobic-association hydrogels; optical images of the self-healing process of hydrogels over time; hydrogel region before and after healing. Reproduced with permission from Ref. [184]. 
a)

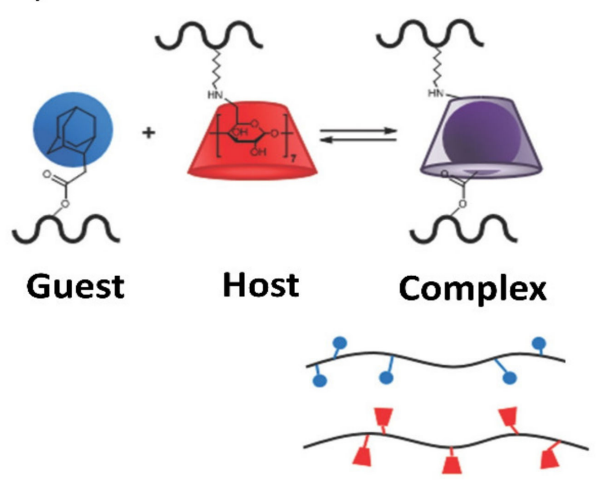

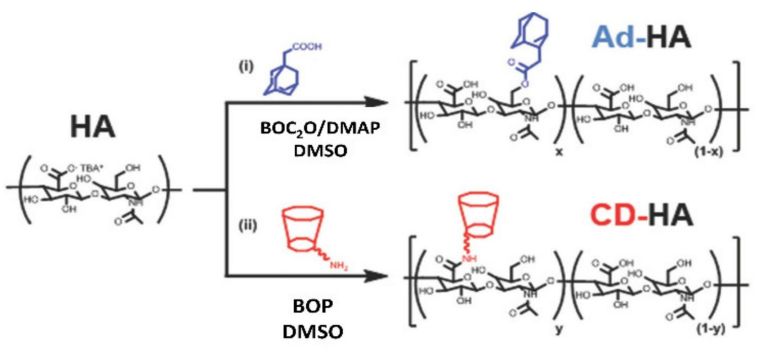

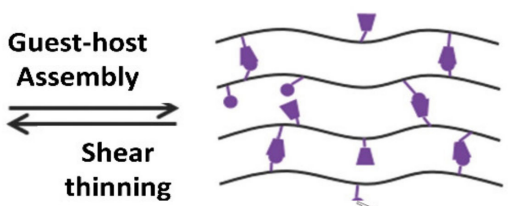

c)
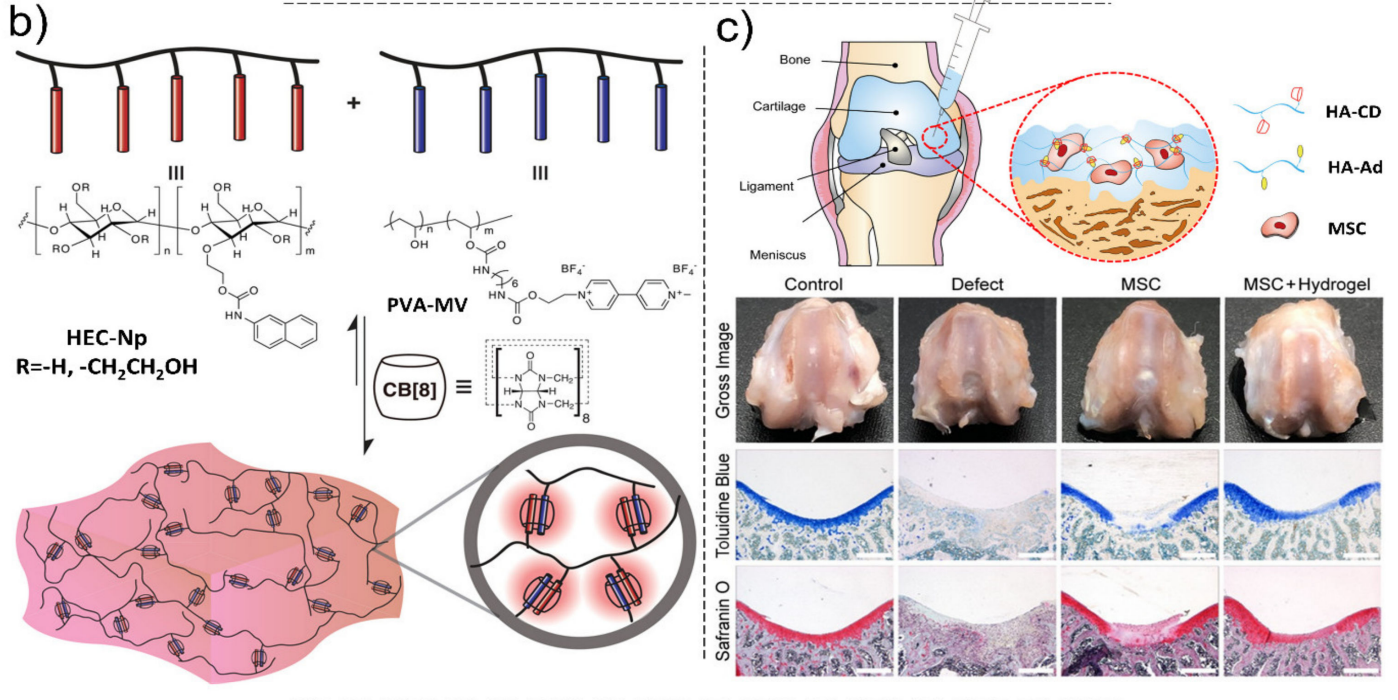

d)

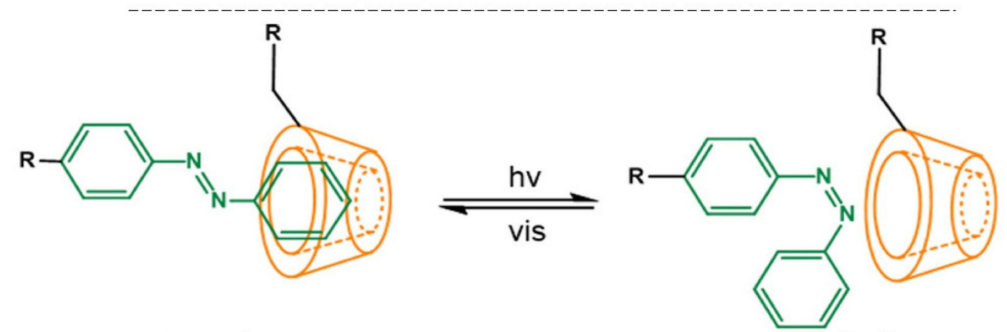

trans-Azo
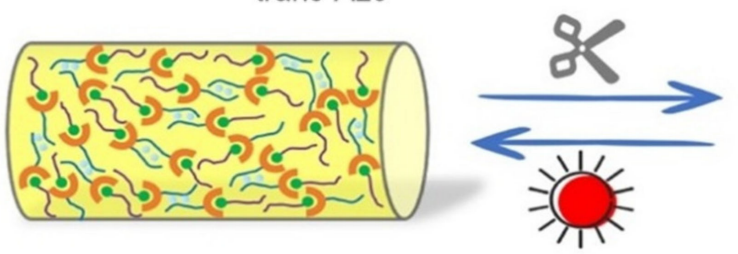

cis-Azo

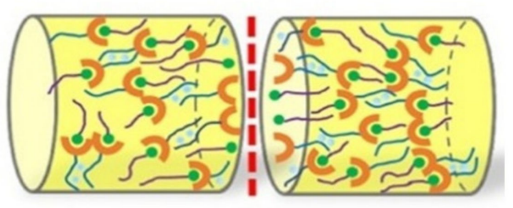

Figure 8. (a) Guest-host hydrogel formation based on the complexation of adamantane and $\beta$-cyclodextrin and corresponding synthesis processes. Schematic representation of hydrogel formation via guest-host interactions. Reproduced with permission from Ref. [193]. (b) Schematic illustration of a supramolecular hydrogel based on host-guest complexation with cucurit[8]uril (CB[8]). Reproduced with permission from Ref. [191]. (c) Left: Schematic illustration for injectable supramolecular hydrogels encapsulating MSCs for cartilage tissue regeneration. Right: optical images and histological analysis of regenerated cartilage tissues after treating with hydrogels and MSCs. Reproduced with permission from Ref. [105]. (d) The host-guest interactions between Azo derivatives and CD derivatives in the presence and absence of light and the schematic illustration of the alginate-based cyclodextrin/azo-polyacrylamide composite self-healing process. Reproduced with permission from Ref. [196]. 
Table 4. Summary of intrinsic mechanisms of self-healing hydrogels in cartilage tissue engineering.

\begin{tabular}{|c|c|c|c|c|c|c|c|}
\hline $\begin{array}{c}\text { Mechanism } \\
\text { Type }\end{array}$ & Materials & $\begin{array}{c}\text { Self- } \\
\text { Healing } \\
\text { Conditions }\end{array}$ & $\begin{array}{l}\text { Time of } \\
\text { Healing }\end{array}$ & Properties & Main Reactions & $\begin{array}{c}\text { Healing } \\
\text { Efficiency }\end{array}$ & Ref. \\
\hline \multirow{9}{*}{$\begin{array}{l}\text { Dynamic } \\
\text { Covalent } \\
\text { interaction }\end{array}$} & Poly(ethylene oxide) & $\begin{array}{c}\text { Room } \\
\text { temperature } \\
(\mathrm{RT}) \text {, acidic } \mathrm{pH}\end{array}$ & $48 \mathrm{~h}$ & $\begin{array}{l}\text { Biocompatible, cell } \\
\text { viability, good } \\
\text { viscoelasticity, } \\
\text { improved } \\
\text { mechanical stability }\end{array}$ & $\begin{array}{l}\text { Acylhydrazone } \\
\text { exchange } \\
\text { reactions, disulfide } \\
\text { exchange reactions }\end{array}$ & $\mathrm{N} / \mathrm{A}$ & [197] \\
\hline & $\begin{array}{l}\text { Chitosan, Dialdehyde } \\
\text { debranched starch } \\
\text { (DADBS) }\end{array}$ & $25^{\circ} \mathrm{C}$ & $<30 \mathrm{~min}$ & $\begin{array}{c}\text { Fast crosslinking } \\
\text { time under } \\
30 \mathrm{~s}, \text { tunable } \\
\text { self-healing, } \\
\text { excellent } \\
\text { viscoelasticity, } \\
\text { and mechanical } \\
\text { properties, } \\
\text { excellent 3D } \\
\text { printability, } \\
\text { obvious } \\
\text { responsiveness } \\
\text { to fluorescence light }\end{array}$ & $\begin{array}{l}\text { Crosslinking by } \\
\text { Schiff-base } \\
\text { reactions between } \\
\text { the aldehyde } \\
\text { groups in DADBS } \\
\text { and the amino } \\
\text { groups in chitosan }\end{array}$ & $100 \%$ & [198] \\
\hline & $\begin{array}{l}\text { O-carboxymethyl } \\
\text { chitosan }\end{array}$ & $\mathrm{RT}$ & - & $\begin{array}{c}\text { Electrostatic } \\
\text { attraction, porous } \\
\text { and interconnected } \\
\text { morphology, } \\
\text { storage modulus, } \\
\text { excellent pH } \\
\text { sensitive swelling } \\
\text { properties }\end{array}$ & $\begin{array}{l}\text { Schiff base reaction } \\
\text { between the amino } \\
\text { groups on the } \\
\text { chitosan and } \\
\text { aldehyde groups of } \\
\text { crosslink agent, } \\
\text { host-guest reaction } \\
\text { of poly ( } \beta \text { - } \\
\text { cyclodextrin) with } \\
\text { diamantine }\end{array}$ & $\geq 97 \%$ & [45] \\
\hline & $\begin{array}{c}\text { Dialdehyde-modified } \\
\text { hyaluronic acid (AHA), } \\
\text { Cystamine } \\
\text { dihydrochloride (Cys) }\end{array}$ & $\begin{array}{c}\text { Ambient } \\
\text { temperature }\end{array}$ & $10 \mathrm{~min}$ & $\begin{array}{c}\text { Fast crosslinking, } \\
\text { improved } \\
\text { mechanical } \\
\text { properties, } \\
\text { bioprintable, } \\
\text { biocompatible }\end{array}$ & $\begin{array}{l}\text { Schiff base reaction } \\
\text { between the } \\
\text { di-aldehyde groups } \\
\text { on AHA and amino } \\
\text { groups on Cys }\end{array}$ & $\sim 100 \%$ & [199] \\
\hline & $\begin{array}{c}\text { Aldehyde-- } \\
\text { functionalized } \\
\text { surface-modified } \\
\text { cellulose nanocrystals } \\
\text { (a-CNCs) }\end{array}$ & RT & - & $\begin{array}{l}\text { Biocompatible, } \\
\text { injectable in situ, } \\
\text { rapid shear } \\
\text { thinning, cell } \\
\text { viability, good } \\
\text { viscoelasticity, } \\
\text { improved } \\
\text { mechanical stability }\end{array}$ & $\begin{array}{l}\text { Schiff-base reaction } \\
\text { between the } \\
\text { aldehyde groups on } \\
\text { a-CNCs and amine } \\
\text { groups on collagen }\end{array}$ & $\sim 100 \%$ & {$[200]$} \\
\hline & $\begin{array}{l}\text { Lactose-modified } \\
\text { chitosan (CTL), Boric } \\
\text { acid, Mannitol }\end{array}$ & RT & $5 \mathrm{~min}$ & $\begin{array}{l}\text { Biocompatible, } \\
\text { excellent } \\
\text { viscoelasticity }\end{array}$ & $\begin{array}{l}\text { Schiff base reactions } \\
\text { between the bronic } \\
\text { groups in boric acid } \\
\text { and the amino } \\
\text { groups in CTL }\end{array}$ & $100 \%$ & [201] \\
\hline & $\begin{array}{c}\text { Triblock(ABA) } \\
\text { copolymers with a } \\
\text { central poly(ethylene } \\
\text { oxide) block and } \\
\text { terminal dithiolane } \\
\text { blocks }\end{array}$ & $25^{\circ} \mathrm{C}$ & $24 \mathrm{~h}$, & $\begin{array}{l}\text { Biocompatible, } \\
\text { excellent } \\
\text { Stiffness and } \\
\text { viscoelasticity, } \\
\text { photosensitive, } \\
\text { mucoadhesive }\end{array}$ & $\begin{array}{l}\text { The reversible } \\
\text { ring-opening } \\
\text { of disulfide } \\
\text { exchange, } \\
\text { the intracellular } \\
\text { redox potential }\end{array}$ & $\mathrm{N} / \mathrm{A}$ & {$[202]$} \\
\hline & $\begin{array}{c}\text { Gelatin, Dialdehyde } \\
\text { carboxymethyl cellulose }\end{array}$ & $37^{\circ} \mathrm{C}$ & $1 \mathrm{~h}$ & $\begin{array}{c}\text { Excellent } \\
\text { biocompatibility, } \\
\text { biodegradability } \\
\text { and non- } \\
\text { immunogenicity, } \\
\text { good fatigue } \\
\text { resistance }\end{array}$ & $\begin{array}{c}\text { Schiff base reaction } \\
\text { between } \\
\text { amino-gelatin and } \\
\text { dialdehyde } \\
\text { carboxymethyl } \\
\text { cellulose }\end{array}$ & $90 \%$ & [203] \\
\hline & $\begin{array}{c}\text { Oxidized alginate (OA), } \\
\text { Semicarbazone } \\
\text { (or hydrazine) }\end{array}$ & RT & $\begin{array}{l}10 \mathrm{~min} \\
\text { (or } 30 \mathrm{~min})\end{array}$ & $\begin{array}{l}\text { Biocompatibility, } \\
\text { excellent stiffness, } \\
\text { viscoelasticity, } \\
\text { spreading of } \\
\text { fibroblasts and cell } \\
\text { adhesion, } \\
\text { printability, } \\
\text { non-cytotoxic }\end{array}$ & $\begin{array}{c}\text { The Divalent bond } \\
\text { between amino } \\
\text { bonds of OA and } \\
\mathrm{Ca}^{+2} \\
\text { of semi-carbazone }\end{array}$ & $70 \%(40 \%)$ & [204] \\
\hline
\end{tabular}


Table 4. Cont

\begin{tabular}{|c|c|c|c|c|c|c|c|}
\hline $\begin{array}{l}\text { Mechanism } \\
\text { Type }\end{array}$ & Materials & $\begin{array}{c}\text { Self- } \\
\text { Healing } \\
\text { Conditions }\end{array}$ & $\begin{array}{l}\text { Time of } \\
\text { Healing }\end{array}$ & Properties & Main Reactions & $\begin{array}{l}\text { Healing } \\
\text { Efficiency }\end{array}$ & Ref. \\
\hline & $\begin{array}{l}\text { Acrylamide-modified } \\
\text { chitin, Oxidized alginate }\end{array}$ & Basic $\mathrm{pH}, 25^{\circ} \mathrm{C}$ & $2 \mathrm{~h}$ & $\begin{array}{c}\text { Good } \\
\text { biocompatibility } \\
\text { and } \\
\text { biodegradability, } \\
\text { excellent viability }\end{array}$ & $\begin{array}{l}\text { Schiff base reactions } \\
\text { between imine } \\
\text { linkages amine } \\
\text { groups of } \\
\text { acrylamide- } \\
\text { modified chitin and } \\
\text { dialdehyde groups } \\
\text { on oxidized alginate }\end{array}$ & $\mathrm{N} / \mathrm{A}$ & [205] \\
\hline & $\begin{array}{c}\text { Chondroitin sulfate } \\
\text { multiple aldehydes } \\
\text { (CSMA), } \\
\text { N-succinyl chitosan (SC) }\end{array}$ & $\begin{array}{l}20^{\circ} \mathrm{C} \text {, high } \\
\text { moisture }\end{array}$ & $2 \mathrm{~h}$ & $\begin{array}{c}\text { Excellent viability, } \\
\text { good } \\
\text { biocompatibility, } \\
\text { and } \\
\text { biodegradability, } \\
\text { finite } \\
\text { inflammatory, } \\
\text { injectable }\end{array}$ & $\begin{array}{c}\text { Schiff base reactions } \\
\text { between } \\
\text { aldehyde groups on } \\
\text { CSMA and amino } \\
\text { groups on SC }\end{array}$ & $\mathrm{N} / \mathrm{A}$ & [206] \\
\hline \multirow{5}{*}{$\begin{array}{l}\text { Hydrogen } \\
\text { interaction }\end{array}$} & $\begin{array}{l}\text { Urethane, Urea, } \\
\text { 2-ureido-4[1H]- } \\
\text { pyrimidinone }\end{array}$ & RT & $48 \mathrm{~h}$ & $\begin{array}{l}\text { Excellent toughness, } \\
\text { tensile strength, } \\
\text { and mechanical } \\
\text { properties }\end{array}$ & $\begin{array}{l}\text { Hierarchical } \\
\text { hydrogen bonding } \\
\text { of urethane and } \\
\text { supramolecular } \\
\text { interaction }\end{array}$ & $90 \%$ & [207] \\
\hline & $\begin{array}{l}\text { Ureido- pyrimidinone } \\
\text { (UPy), Functionalized } \\
\text { dextran }\end{array}$ & $20^{\circ} \mathrm{C}$ & $10 \mathrm{~min}$ & $\begin{array}{c}\text { Biocompatible, } \\
\text { good } \\
\text { mechanical } \\
\text { properties }\end{array}$ & $\begin{array}{l}\text { Ureido- } \\
\text { pyrimidinone (UPy)- } \\
\text { functionalized } \\
\text { dextran }\end{array}$ & $100 \%$ & [11] \\
\hline & $\begin{array}{c}\text { 2-ureido-4[1H]- } \\
\text { pyrimidinone (UPy), } \\
\text { Poly(ethylene glycol) } \\
\text { (PEG) }\end{array}$ & RT & $\mathrm{N} / \mathrm{A}$ & $\begin{array}{c}\text { Tunable mechanical } \\
\text { properties, shape } \\
\text { memory } \\
\text { behavior. Tough }\end{array}$ & $\begin{array}{c}\text { Hydrogen-bonding } \\
\text { between UPy and } \\
\text { PEG }\end{array}$ & $\mathrm{N} / \mathrm{A}$ & [208] \\
\hline & $\begin{array}{c}\text { Polyurethane (PU), } \\
\text { Tannin, Acid- modified } \\
\text { nano tungsten disulfide }\end{array}$ & RT & $12 \mathrm{~h}$ & $\begin{array}{c}\text { Excellent } \\
\text { mechanical strength } \\
\text { and tensile }\end{array}$ & $\begin{array}{c}\text { Noncovalent } \\
\text { bonding connection } \\
\text { of nano filer, } \\
\text { interfacial hydrogen } \\
\text { bonds between } \\
\text { TA-WS2 and PU }\end{array}$ & $100 \%$ & [209] \\
\hline & $\begin{array}{c}\text { Cucurbit }[8] \text { uril }(\mathrm{CB}[8]), \\
\text { Acrylamide, } \\
\text { N,N'-bismethylene } \\
\text { bisacrylamide }\end{array}$ & RT & Very fast & $\begin{array}{l}\text { Good mechanical } \\
\text { properties }\end{array}$ & $\begin{array}{c}\text { Hydrogen bond } \\
\text { and Supramolecular } \\
\text { interaction between } \\
\mathrm{CB}[8] \text { and } \\
\text { acrylamide, } \\
\text { covalent }\end{array}$ & $\mathrm{N} / \mathrm{A}$ & [185] \\
\hline \multirow{3}{*}{$\begin{array}{c}\text { Ionic } \\
\text { interaction }\end{array}$} & $\begin{array}{l}2- \\
\text { hydroxypropyltrimethyl } \\
\text { ammonium chloride } \\
\text { chitosan (HACC), } \\
\text { Poly(acrylic acid) } \\
\text { (PAAc)-Fe }\end{array}$ & $70^{\circ} \mathrm{C}$ & $48 \mathrm{~h}$ & $\begin{array}{l}\text { Excellent } \\
\text { mechanical } \\
\text { properties, tough } \\
\text { and transparent }\end{array}$ & $\begin{array}{c}\text { Both } \\
\text { macromolecular } \\
\text { positively charged } \\
\text { HACC and Fe }{ }^{3+} \\
\text { metal ions acted as } \\
\text { cross-linkers to form } \\
\text { ionic bonds with } \\
\text { negatively charged } \\
\text { PAAc }\end{array}$ & $74 \%$ & [210] \\
\hline & $\begin{array}{c}\text { Chitosan, Arginine } \\
\text { (Arg), Tripolyphosphate } \\
\text { (TPP) }\end{array}$ & RT & $48 \mathrm{~h}$ & $\begin{array}{l}\text { Tunable structural } \\
\text { and chemical } \\
\text { physical properties }\end{array}$ & $\begin{array}{c}\text { Reaction of } \\
\text { Polyanions of TPP } \\
\text { and cations of } \\
\text { amino acid arginin }\end{array}$ & $\mathrm{N} / \mathrm{A}$ & [211] \\
\hline & $\begin{array}{l}\text { Ammonium persulfate } \\
\text { (APS), N,N,N } \mathrm{N}^{\prime}, \mathrm{N}^{\prime}- \\
\text { tetramethylethylenedi } \\
\text { amine (TEMED) }\end{array}$ & $\mathrm{RT}, \mathrm{pH} \leq 3$ & $\mathrm{~N} / \mathrm{A}$ & $\begin{array}{l}\text { Anti-fatigue, good } \\
\text { mechanical } \\
\text { properties, } \\
\text { time-independent } \\
\text { healing }\end{array}$ & $\begin{array}{c}\text { Positively and } \\
\text { negatively charged } \\
\text { groups of APS and } \\
\text { TEMED }\end{array}$ & $66-73 \%$ & [212] \\
\hline \multirow{4}{*}{$\begin{array}{l}\text { Supramolecular } \\
\text { Interaction }\end{array}$} & $\begin{array}{c}\beta \text {-cyclodextrin modified } \\
\text { alginate (Alg-CD) } \\
\text { Adamantine modified } \\
\text { graphene oxide, }\end{array}$ & RT & $12 \mathrm{~h}$ & $\begin{array}{l}\text { Injectable, good cell } \\
\text { adhesion and } \\
\text { differentiation, } \\
\text { excellent } \\
\text { mechanical } \\
\text { properties }\end{array}$ & $\begin{array}{l}\text { Guest-host } \\
\text { interactions }\end{array}$ & $100 \%$ & [213] \\
\hline & $\begin{array}{c}\text { Adamantane } \\
\text { functionalized } \\
\text { hyaluronic acid, } \\
\beta \text {-Cyclodextrin }\end{array}$ & RT & $12 \mathrm{~h}$ & $\begin{array}{l}\text { Photo-cross-linkable } \\
\text { compressible }\end{array}$ & $\begin{array}{l}\text { Guest-host } \\
\text { interactions }\end{array}$ & $\mathrm{N} / \mathrm{A}$ & [157] \\
\hline & $\begin{array}{l}\beta \text {-cyclodextrin, } \\
\text { adamantine bound by } \\
\text { peptide tether to } \\
\text { Hyaluronic acid }\end{array}$ & $37^{\circ} \mathrm{C}$ & Fast & $\begin{array}{l}\text { Injectable, good cell } \\
\text { adhesion and } \\
\text { differentiation, } \\
\text { excellent } \\
\text { mechanical stability }\end{array}$ & $\begin{array}{l}\text { Guest-host } \\
\text { interactions }\end{array}$ & $100 \%$ & [214] \\
\hline & $\begin{array}{c}\beta \text {-cyclodextrin-, } \\
\alpha \text {-bromonaphthalene } \\
\text { functionalized } \\
\text { acrylamide }\end{array}$ & $20^{\circ} \mathrm{C}$ & $1 \mathrm{~min}-1 \mathrm{~h}$ & $\begin{array}{l}\text { Injectable, excellent } \\
\text { mechanical } \\
\text { properties }\end{array}$ & $\begin{array}{l}\text { Guest-host } \\
\text { interactions }\end{array}$ & $\mathrm{N} / \mathrm{A}$ & [215] \\
\hline
\end{tabular}


Table 4. Cont

\begin{tabular}{|c|c|c|c|c|c|c|c|}
\hline $\begin{array}{c}\text { Mechanism } \\
\text { Type }\end{array}$ & Materials & $\begin{array}{c}\text { Self- } \\
\text { Healing } \\
\text { Conditions }\end{array}$ & $\begin{array}{l}\text { Time of } \\
\text { Healing }\end{array}$ & Properties & Main Reactions & $\underset{\text { Efficiency }}{\text { Healing }}$ & Ref. \\
\hline & $\begin{array}{c}\beta \text { Cholic-acid, } \\
\beta \text {-cyclodextrin- } \\
\text { functionalized } \\
\text { N,N'- } \\
\text { dimethylacrylamide }\end{array}$ & $20^{\circ} \mathrm{C}$ & $<1 \min$ & $\begin{array}{l}\text { Injectable, } \\
\text { degradable }\end{array}$ & $\begin{array}{l}\text { Guest-host } \\
\text { interaction }\end{array}$ & $97 \%$ & [216] \\
\hline \multirow{2}{*}{$\begin{array}{l}\text { Hydrophobic } \\
\text { interaction }\end{array}$} & $\begin{array}{c}\text { Acrylamide, Octyl } \\
\text { phenol } \\
\text { polyethoxy ether } \\
\text { acrylate copolymer }\end{array}$ & RT & 6 days & $\begin{array}{c}\text { Excellent } \\
\text { mechanical } \\
\text { properties, flexible }\end{array}$ & $\begin{array}{l}\text { Micelles between } \\
\text { the hydrophobic } \\
\text { acrylates and } \\
\text { sodium } \\
\text { dodecyl sulfate }\end{array}$ & $70 \%$ & [175] \\
\hline & $\begin{array}{c}\text { Cellulose nanowhiskers } \\
\text { (CNW), Acrylamide } \\
\text { (AM), Stearyl } \\
\text { methacrylate, Sodium } \\
\text { dodecylsulfat (SDS) }\end{array}$ & RT & $60 \mathrm{~min}$ & $\begin{array}{l}\text { Excellent } \\
\text { mechanical } \\
\text { properties, } \\
\text { stretchable }\end{array}$ & $\begin{array}{c}\text { Hydrophobic } \\
\text { interaction of CNW } \\
\text { and AM }\end{array}$ & $100 \%$ & [217] \\
\hline
\end{tabular}

Despite extensive research on improving the mechanical strength of self-healing hydrogels, these systems still encounter serious challenges within the vibrant and mechanically demanding environment. To address this issue, scientists have developed hydrogels crosslinked via multiple dynamic as well as covalent bonds. While the number of research articles reporting self-healing hydrogels with multiple crosslinks for cartilage tissue engineering is limited, Table 5 summarizes the recent studies with potential applications in CTE. Qin et al. studied using reversible noncovalent bonds along with permanent covalent crosslinks to increase the mechanical strength of hydrogel to $34.0 \mathrm{MPa}$ [218]. Yanagisawa and coworkers fabricated noncovalently crosslinked hydrogels with a low molecular weight and tensile strength of almost 26.5 MPa [219]. Ding et al. fabricated cross-linked hydrogel via both ionic- and hydrogen-bonds by applying acrylic acid and acrylamide, xanthan gum, and guar gum, which demonstrated excellent mechanical characteristics and moderate water content for use in the CTE [205].

Table 5. Summary of the recent studies on self-healing hydrogels with multiple crosslinks for CTE applications.

\begin{tabular}{|c|c|c|c|}
\hline Hydrogels (Materials) & Bonding Mechanisms & Properties & Ref. \\
\hline $\begin{array}{l}\text { Polyvinyl } \\
\text { alcohol/poly(3,4-ethylenedioxythiophene)/sulfosuccinic acid }\end{array}$ & $\begin{array}{c}\text { H-bonding } \\
\text { Crystallization } \\
\text { Electrostatic interactions }\end{array}$ & $\begin{array}{l}\text { High water content }(75 \mathrm{wt} \%) \\
\text { High tensile stress }(\sim 2.5 \mathrm{MPa}) \\
\text { Large elongation }(>600 \%) \\
\text { Conductivity }(\sim 25 \mathrm{mS} / \mathrm{cm})\end{array}$ & [220] \\
\hline Carboxymethyl cellulose/borate/gelatin & $\begin{array}{l}\text { Schiff-base reaction } \\
\text { Boronate-diol complexation }\end{array}$ & $\mathrm{pH}$ and glucose responsive & [221] \\
\hline $\begin{array}{c}\text { P(urea-IL1-SPMA1)-3d } \\
\text { IL: imidazolium-based ionic liquid } \\
\text { SPMA: 3-sulfopropyl methacrylate potassium salt }\end{array}$ & $\begin{array}{l}\text { H-bonding } \\
\text { Ionic interaction }\end{array}$ & $\begin{array}{l}\text { Tensile strength of } \sim 1.3 \mathrm{MPa} \\
\text { Strain at break of } \sim 720 \% \\
\text { Toughness of } \sim 6.7 \mathrm{MJ} / \mathrm{m}^{3}\end{array}$ & [222] \\
\hline $\begin{array}{c}\text { Laponite }^{\circledR} \text { nano-clay, hydroxyapatite, poly-L-arginine, } \\
\text { sodium polyacrylate }\end{array}$ & $\begin{array}{l}\text { H-bonding } \\
\text { Electrostatic interactions }\end{array}$ & - & [223] \\
\hline $\begin{array}{c}\text { Poly(diallyldimethylammonium chloride)/branched } \\
\text { poly(ethylenimine)/poly(sodium } \\
\text { 4-styrenesulfonate)/poly(acrylic acid) }\end{array}$ & $\begin{array}{l}\text { H-bonding } \\
\text { Electrostatic interactions }\end{array}$ & $\begin{array}{l}\text { Tensile strength: } 1.26 \mathrm{MPa} \\
\text { Strain at break: } 2434.2 \% \\
\text { Toughness: } 19.53 \mathrm{MJ} / \mathrm{m}^{3}\end{array}$ & [224] \\
\hline $\begin{array}{l}\text { Free radical polymerization of acrylic acid/acrylamide in the } \\
\text { presence of chitosan }\end{array}$ & $\begin{array}{c}\text { H-bonding } \\
\text { Electrostatic interactions }\end{array}$ & $\begin{array}{l}\text { High water content }(<90 \%) \\
\text { Strain at break }<625 \%) \\
\text { High self-healing efficiency } \\
\qquad(<88 \%)\end{array}$ & [225] \\
\hline $\begin{array}{l}\text { Functionalized single-wall carbon nanotube/polyvinyl } \\
\text { alcohol/polydopamine }\end{array}$ & $\begin{array}{l}\text { H-bonding } \\
\pi-\pi \text { interactions }\end{array}$ & $\begin{array}{c}\text { Fast self-healing ability }(\sim 2 \mathrm{~s}) \\
\text { High self-healing efficiency } \\
(99 \%) \\
\text { Robust adhesiveness }\end{array}$ & [226] \\
\hline Amoc (9-anthracenemethoxycarbonyl)-capped dipeptides & $\begin{array}{l}\text { H-bonding } \\
\pi-\pi \text { interactions }\end{array}$ & Antibacterial efficacy & [227] \\
\hline $\begin{array}{l}\text { Hyaluronic acid-graft-dopamine and reduced graphene } \\
\text { oxide/using a } \mathrm{H}_{2} \mathrm{O}_{2} / \mathrm{HPR} \text { (horseradish peroxidase) }\end{array}$ & $\begin{array}{l}\text { H-bonding } \\
\pi-\pi \text { interactions }\end{array}$ & $\begin{array}{c}\text { Antioxidant activity } \\
\text { Photothermal effect } \\
\text { Adhesive hydrogel } \\
\text { Hemostatic hydrogel } \\
\text { Conductive hydrogel }\end{array}$ & [228] \\
\hline $\begin{array}{l}\text { Casein sodium salt from bovine } \\
\text { milk/polydopamine/polyacrylamide }\end{array}$ & $\begin{array}{l}\text { H-bonding } \\
\pi-\pi \text { interactions }\end{array}$ & $\begin{array}{l}\text { Super-stretchability } \\
\text { Excellent fatigue resistance } \\
\text { Rapid self-healing }\end{array}$ & [229] \\
\hline
\end{tabular}


Table 5. Cont

\begin{tabular}{|c|c|c|c|}
\hline Hydrogels (Materials) & Bonding Mechanisms & Properties & Ref. \\
\hline $\begin{array}{l}\text { Poly (styrene-acrylic acid) core-shell nanoparticles/free radical } \\
\text { copolymerization of acrylamide and stearyl methylacrylate }\end{array}$ & $\begin{array}{c}\text { H-bonding } \\
\text { Hydrophobic interactions }\end{array}$ & $\begin{array}{c}\text { Excellent self-healing } \\
\text { Good mechanical properties }\end{array}$ & [230] \\
\hline Alginate aldehyde/poly (acrylamide) & $\begin{array}{l}\text { Schiff-base reaction } \\
\text { H-bonding }\end{array}$ & $\begin{array}{l}\text { Excellent self-healing and } \\
\text { mechanical properties }\end{array}$ & [231] \\
\hline $\begin{array}{l}\text { Glycol chitosan/cellulose nanofiber/telechelic difunctional } \\
\text { polyethylene glycol }\end{array}$ & $\begin{array}{l}\text { Schiff-base reaction } \\
\text { H-bonding }\end{array}$ & $\begin{array}{l}\text { Injectability (neural stem cells } \\
\text { delivery) }\end{array}$ & [232] \\
\hline $\begin{array}{l}\text { Salicylaldehyde benzoyl hydrazone-terminal poly(ethylene } \\
\text { glycol) } / \mathrm{Ni}^{2+}\end{array}$ & $\begin{array}{l}\text { Metal-ligand coordination } \\
\text { Hydrophobic interactions }\end{array}$ & $\begin{array}{c}\text { Rapid self-healing } \\
\text { Reversible pH-responsiveness }\end{array}$ & [233] \\
\hline $\begin{array}{l}\text { Adamantane and } \beta \text {-cyclodextrin modified hyaluronic } \\
\text { acid/methacrylated hyaluronic acid }\end{array}$ & $\begin{array}{c}\text { Michael addition crosslinking } \\
\text { (covalent reaction) } \\
\text { Host-guest interactions }\end{array}$ & $\begin{array}{c}\text { Injectability } \\
\text { Rapid self-healing } \\
\text { Cytocompatibility } \\
\text { Mechanical toughness }\end{array}$ & [234] \\
\hline
\end{tabular}

\section{Fabrication Methods}

The precise fabrication of bio-scaffolds is among the main aims of tissue engineering research. Traditional scaffold fabrication techniques such as foam processing, solution casting, and freeze-drying have limited control on the chemistry, macrostructure, and porosity of final products. Electrospinning and 3D bioprinting are two advanced manufacturing technologies for making desirable tissue engineering scaffolds [235,236]. Scaffolds prepared using these two techniques are hollow matrices that support cell structures and improve cell adhesion and proliferation due to their highly porous geometry which facilitate the transport of oxygen, nutrients, and biological wastes. The most popular fabricating methods are listed in Table 6.

Table 6. Comparison among fabrication methods in tissue engineering.

\begin{tabular}{|c|c|c|c|c|}
\hline Method & Main Characteristic & Resulted Porosity & $\begin{array}{c}\text { Cell } \\
\text { Viability }\end{array}$ & Ref. \\
\hline Freeze casting & $\begin{array}{l}\text { Ceramic slurries are used in this } \\
\text { method; then, water is evaporated. It } \\
\text { produces pores due to formation of } \\
\text { ice crystals. }\end{array}$ & $<85 \%$ & $<90 \%$ & [237] \\
\hline Freeze-drying & $\begin{array}{l}\text { It is an easy procedure that can be } \\
\text { applied with natural materials such } \\
\text { as collagen and fibers. The porosity can } \\
\text { be improved by freezing temperature } \\
\text { alterations and changing of the } \\
\text { concentration of materials. }\end{array}$ & $30 \%-80 \%$ & $<90 \%$ & {$[238]$} \\
\hline $\begin{array}{l}\text { Solvent casting and } \\
\text { Particle leaching }\end{array}$ & $\begin{array}{l}\text { It uses casting molds to produce 3D } \\
\text { scaffolds by polymer solution. Then, } \\
\text { it requires leaching by using organic } \\
\text { solvents to simplify the addition of } \\
\text { drugs or growth factors to scaffolds. }\end{array}$ & $50 \%-90 \%$ & $75 \%-88 \%$ & [239] \\
\hline Gas foaming & $\begin{array}{l}\text { Using high-pressure carbon dioxide for } \\
\text { expanding the polymer matrix without } \\
\text { applying high temperature or toxic } \\
\text { solvents. Changing pressure can also } \\
\text { create scaled porous scaffolds. }\end{array}$ & $<90 \%$ & $\mathrm{~N} / \mathrm{A}$ & {$[240]$} \\
\hline Phase separation & $\begin{array}{l}\text { Changing temperature for polymer and } \\
\text { solvent separation results in a solid } \\
\text { polymer due to phase separation. } \\
\text { Finally, a desirable, homogenous, } \\
\text { and interconnected porous scaffold is } \\
\text { produced depending on cooling rates. }\end{array}$ & $60 \%-98 \%$ & $<98 \%$ & {$[241]$} \\
\hline Electrospinning & $\begin{array}{l}\text { Nanoscale or microscale fibers are } \\
\text { produced by tuning process parameters } \\
\text { and chemicals in this method. }\end{array}$ & $80 \%-95 \%$ & $<80 \%$ & {$[242,243]$} \\
\hline
\end{tabular}


Table 6. Cont.

\begin{tabular}{|c|c|c|c|c|}
\hline Method & Main Characteristic & Resulted Porosity & $\begin{array}{c}\text { Cell } \\
\text { Viability }\end{array}$ & Ref. \\
\hline Sol-gel & $\begin{array}{l}\text { Colloidal metal oxides are applied } \\
\text { traditionally to create tunable porous } \\
\text { scaffolds in the sol-gel method with } \\
\text { desirable chemistry. Double phasic } \\
\text { chitosan scaffolds with a conjunction } \\
\text { peptide have demonstrated the } \\
\text { capability to recruit stem cells for } \\
\text { cartilage repair. }\end{array}$ & $\mathrm{N} / \mathrm{A}$ & $\mathrm{N} / \mathrm{A}$ & [244] \\
\hline Additive manufacturing & $\begin{array}{l}\text { Extrusion methods in biomedical } \\
\text { applications are often polymer-based } \\
\text { and provide benefits in cost, size, and } \\
\text { flexibility against old manufacturing } \\
\text { methods. Both polymers and metals can } \\
\text { be used in solid free-form sintering, } \\
\text { while laser melting is limited to metals. }\end{array}$ & $80 \%-90 \%$ & $60 \%-95 \%$ & [245] \\
\hline
\end{tabular}

3D printing, a growing additive manufacturing technology for fabricating precise 3D structures, is currently widely used to increase the applicability and functions of cell-laden scaffolds. During the recent decay, tissue engineering has shown promising results for treatment of osteoarticular damage and has provided a suitable alternative to current therapies using 3D bioprinting methods in the clinical environment such as the use of various biomaterial scaffolds, allogeneic and autologous of chondrocytes bases, chondroprogenitor cells and growth factors, and mixtures of them [235]. The bioprinting process is based on the combination of various living cell-laden biomaterials referred to as bioinks [246,247]. The physicochemical properties of bioinks are very important to produce functionally live tissues such as cartilage. Thus, bioinks should have biological properties, biodegradability, and printability. Generally, hydrogels are a suitable candidate for bioinks preparation [17]. Figure 9 schematically presents the most important properties of bioinks and their effects on bioprinted constructs. With regards to cartilage regeneration, the hydrogel-based scaffolds are the primary biomaterials applied due to their bioadhesion and compatibility with the surrounding cartilage tissue environment. The physicochemical properties such as swelling ratio, surface tension, gelation time, and rheological parameters are the main factors affecting the printability of a hydrogel solution $[17,236]$. Roseti et al. reviewed the recent advances in bioprinting 3D scaffolds embedded with stem cells for CTE [248]. Additionally, Semba et al. introduced state-of-the-art 3D bioprinting techniques in cartilage and bone design for orthopedic applications [246]. Sadeghianmaryan et al. investigated the printability of chitosan scaffolds. They studied the effect of methods of drying, concentration, and crosslinking density on scaffold properties. They exhibited that the drying method is a critical character in the mechanical and biological performance of chitosan scaffolds. Additionally, smaller pore sizes and higher elastic modulus occur in higher crosslinking density at chitosan concentration of 10\% [44]. Until now, many approaches have been reported for the production of proper bioinks, for the prediction of mechanical properties of a hydrogel structure after bioprinting, type of materials and additives, cell density, and material-cell interaction [249]. 


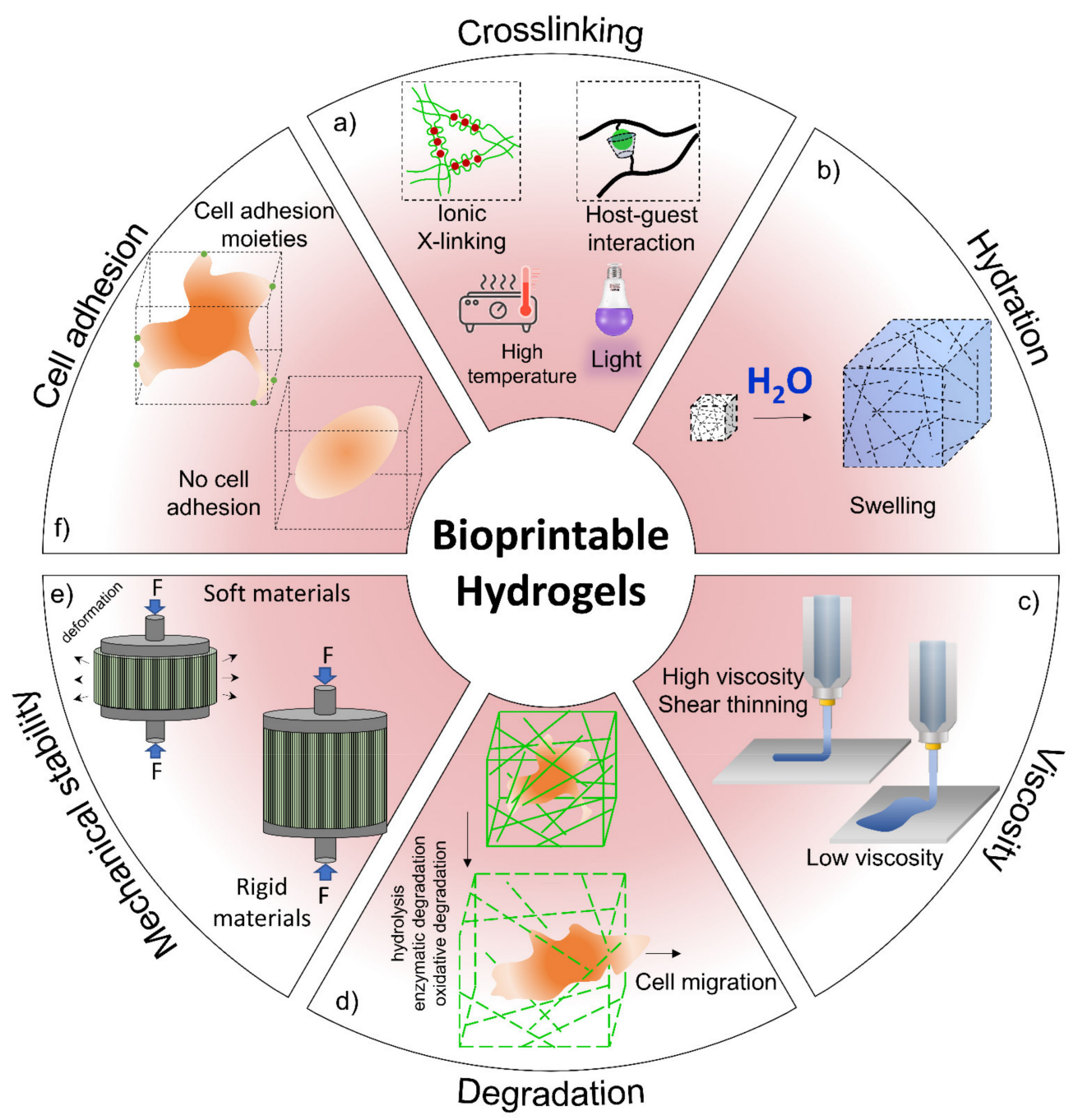

Figure 9. Hydrogel properties in bioprinting. (a) The crosslinking mechanism is related to polymer types that impact cell viability and structure properties. (b) Hydration of a hydrogel system facilitates nutrients and wastes transport within a printed structure. (c) Cell adhesion that supports cell proliferation and migration can be controlled by changing the polymer type. (d) Degradation mechanisms can influence cellular migration. (e) The durability of 3D printed structures is essential to mimic native tissue biomechanical properties and to retain the shape of constructs during cellular growth. (f) Viscous solutions can suspend and protect cells from shear stress inside an extrusion nozzle and reduce flowability of hydrogels after printing (low viscosity solutions can avoid clogging; however, cell settling may occur).

\section{Conclusions and Perspective Remarks}

Over the past decades, self-healing of damaged organs (due to trauma or degenerative pathology) in biological systems inspired researchers to develop new biomaterials able to mimic natural organs' ECMs. Among these materials, hydrogels are attractive for clinical applications because of their high-water content and physicochemical properties, like what are found in native human tissues. Currently, with the advances of synthetic methods, a range of self-healing hydrogels has been expanded, introducing a new class of premium materials for specific applications in cartilage and bone repairing. However, current self-healing biomaterials are considerably suffering from weak and inadequate physicochemical and spatiotemporal properties and high production costs. Although various reversible bonding strategies are currently available for the development of new self-healing hydrogels, they do not meet all the specifications (e.g., high toughness and excellent elasticity, rapid self-healing, excellent integration with surrounding cartilage tissue, sufficient nutrition transportation, drugs and growth factors delivery, and printability) required for CTE. 
On the other hand, clinical applications of new biomaterials can be limited by the cost and difficulty of passing safety and regulatory processes. FDA approval can pose a significant challenge to biomaterial-based therapies as new biomaterials need to meet FDA standards. Materials other than those already approved for use in humans have extensive requirements in quality control and safety. Therefore, when combining cells and materials, considerable animal and clinical testing is required, which comes with high costs and lengthy development timelines [250,251].

The creation of multi-functional self-healing hydrogels with multiple covalent/noncovalent bonds can significantly impact the future of CTE. Designing new materials using mathematical modeling and simulation methods offers interesting and cost-effective opportunities for generating new hydrogels mimicking the native tissue microenvironment. Modifications of currently available models would be another future direction to precisely predict the mechanical properties of hydrogels used for cartilage tissue regeneration $[244,252,253]$.

Undoubtedly, one of the most promising future trends in the development of hydrogels is the combination of advanced hydrogels (nanomaterials, supramolecular, multi-materials, and IPNs) to make new composites with superior properties compared with every individual component. Combining high-performance hydrogels with the novel structure design, biological activity, and superior properties such as self-healing is a promising approach to repair cartilage defects. However, the lack of control over the structure of newly developed tissues is another challenge that can be addressed via multi-component 3D bioprinting technologies benefiting from higher resolution and faster printing speeds. The combination biofabrication methods are a relatively new approach in fabrication of bio-mimicking, heterogeneous, and complex tissue structures. Organ-on-a-chip, as an emerging technology that combines cell biology, engineering techniques, and biomaterials, can be utilized to simulate organs' microenvironments on a microfluidic chip. These organ models recapitulating the main features of human physiopathology are highly desired to investigate new materials in terms of cell-tissue interfaces and metabolic performance. The combination of organ-on-a-chip and 3D bioprinting can provide even more realistic osteoarthritis models for testing new therapies. The opportunities for combination of approaches are tremendous and should motivate the field to push past technical and regulatory barriers, especially with the growing interest in personalized therapeutic approaches.

Author Contributions: All authors read and revised the manuscript. All authors have read and agreed to the published version of the manuscript.

Funding: Pooya Davoodi greatly appreciates financial support from Keele University, School of Pharmacy and Bioengineering starting grant and Faculty Research Award 2021, Keele University, UK.

Institutional Review Board Statement: Not applicable.

Informed Consent Statement: Not applicable.

Data Availability Statement: The data presented in this study are available on request from the corresponding author.

Conflicts of Interest: The authors declare no conflict of interest.

\section{References}

1. Krishnan, Y.; Grodzinsky, A.J. Cartilage diseases. Matrix Biol. 2018, 71, 51-69. [CrossRef]

2. Killen, M.-C.; Charalambous, C.P. Advances in cartilage restoration techniques. In Advances in Medical and Surgical Engineering; Elsevier: Amsterdam, The Netherlands, 2020; pp. 71-83.

3. Ngadimin, K.D.; Stokes, A.; Gentile, P.; Ferreira, A.M. Biomimetic hydrogels designed for cartilage tissue engineering. Biomater. Sci. 2021, 9, 4246-4259. [CrossRef]

4. Wei, W.; Ma, Y.; Yao, X.; Zhou, W.; Wang, X.; Li, C.; Lin, J.; He, Q.; Leptihn, S.; Ouyang, H. Advanced hydrogels for the repair of cartilage defects and regeneration. Bioact. Mater. 2021, 6, 998-1011. [CrossRef]

5. Lin, H.; Yin, C.; Mo, A.; Hong, G. Applications of Hydrogel with Special Physical Properties in Bone and Cartilage Regeneration. Materials 2021, 14, 235. [CrossRef] 
6. Talebian, S.; Mehrali, M.; Taebnia, N.; Pennisi, C.P.; Kadumudi, F.B.; Foroughi, J.; Hasany, M.; Nikkhah, M.; Akbari, M.; Orive, G. Self-healing hydrogels: The next paradigm shift in tissue engineering. Adv. Sci. 2019, 6, 1801664. [CrossRef]

7. Ghomi, E.R.; Neisiany, R.E.; Khorasani, S.N.; Dinari, M.; Ataei, S.; Koochaki, M.S.; Ramakrishna, S. Development of an epoxy self-healing coating through the incorporation of acrylic acid-co-acrylamide copolymeric gel. Prog. Org. Coat. 2020, $149,105948$. [CrossRef]

8. Panahi, P.; Khorasani, S.N.; Koochaki, M.S.; Dinari, M.; Das, O.; Neisiany, R.E. Synthesis of Cloisite 30B-acrylamide/acrylic acid nanogel composite for self-healing purposes. Appl. Clay Sci. 2021, 210, 106174. [CrossRef]

9. Wang, Y.; Adokoh, C.K.; Narain, R. Recent development and biomedical applications of self-healing hydrogels. Expert Opin. Drug Deliv. 2018, 15, 77-91. [CrossRef] [PubMed]

10. Esmaeely Neisiany, R.; Enayati, M.S.; Sajkiewicz, P.; Pahlevanneshan, Z.; Ramakrishna, S. Insight Into the Current Directions in Functionalized Nanocomposite Hydrogels. Front. Mater. 2020, 7, 25. [CrossRef]

11. Hou, S.; Wang, X.; Park, S.; Jin, X.; Ma, P.X. Rapid self-integrating, injectable hydrogel for tissue complex regeneration. Adv. Healthc. Mater. 2015, 4, 1491-1495. [CrossRef]

12. Taylor, D.L.; in het Panhuis, M. Self-healing hydrogels. Adv. Mater. 2016, 28, 9060-9093. [CrossRef] [PubMed]

13. Liu, M.; Zeng, X.; Ma, C.; Yi, H.; Ali, Z.; Mou, X.; Li, S.; Deng, Y.; He, N. Injectable hydrogels for cartilage and bone tissue engineering. Bone Res. 2017, 5, 1-20. [CrossRef] [PubMed]

14. Yang, J.; Zhang, Y.S.; Yue, K.; Khademhosseini, A. Cell-laden hydrogels for osteochondral and cartilage tissue engineering. Acta Biomater. 2017, 57, 1-25. [CrossRef]

15. Zhang, X.; Zhang, W.; Yang, M. Application of hydrogels in cartilage tissue engineering. Curr. Stem Cell Res. Ther. 2018, 13, 497-516. [CrossRef] [PubMed]

16. Vega, S.L.; Kwon, M.Y.; Burdick, J.A. Recent advances in hydrogels for cartilage tissue engineering. Eur. Cells Mater. 2017, $33,59$. [CrossRef]

17. Abdollahiyan, P.; Oroojalian, F.; Mokhtarzadeh, A.; de la Guardia, M. Hydrogel-Based 3D Bioprinting for Bone and Cartilage Tissue Engineering. Biotechnol. J. 2020, 15, 2000095. [CrossRef]

18. Salati, M.A.; Khazai, J.; Tahmuri, A.M.; Samadi, A.; Taghizadeh, A.; Taghizadeh, M.; Zarrintaj, P.; Ramsey, J.D.; Habibzadeh, S.; Seidi, F. Agarose-based biomaterials: Opportunities and challenges in cartilage tissue engineering. Polymers 2020, 12, 1150. [CrossRef]

19. Little, C.J.; Bawolin, N.K.; Chen, X. Mechanical properties of natural cartilage and tissue-engineered constructs. Tissue Eng. Part B: Rev. 2011, 17, 213-227. [CrossRef]

20. Lin, W.; Klein, J. Recent progress in cartilage lubrication. Adv. Mater. 2021, 33, 2005513. [CrossRef]

21. Jahn, S.; Seror, J.; Klein, J. Lubrication of articular cartilage. Annu. Rev. Biomed. Eng. 2016, 18, 235-258. [CrossRef]

22. Kuiper, N.; Sharma, A. A detailed quantitative outcome measure of glycosaminoglycans in human articular cartilage for cell therapy and tissue engineering strategies. Osteoarthr. Cartil. 2015, 23, 2233-2241. [CrossRef]

23. Zhang, Y.; Yu, J.; Ren, K.; Zuo, J.; Ding, J.; Chen, X. Thermosensitive hydrogels as scaffolds for cartilage tissue engineering. Biomacromolecules 2019, 20, 1478-1492. [CrossRef]

24. Cutcliffe, H.C.; DeFrate, L.E. Comparison of cartilage mechanical properties measured during creep and recovery. Sci. Rep. 2020, 10, 1-8. [CrossRef] [PubMed]

25. Oinas, J.; Ronkainen, A.; Rieppo, L.; Finnilä, M.; Iivarinen, J.; van Weeren, P.; Helminen, H.; Brama, P.; Korhonen, R.; Saarakkala, S. Composition, structure and tensile biomechanical properties of equine articular cartilage during growth and maturation. Sci. Rep. 2018, 8, 1-12. [CrossRef]

26. Peters, A.E.; Akhtar, R.; Comerford, E.J.; Bates, K.T. The effect of ageing and osteoarthritis on the mechanical properties of cartilage and bone in the human knee joint. Sci. Rep. 2018, 8, 1-13. [CrossRef]

27. Bos, E.J.; Pluemeekers, M.; Helder, M.; Kuzmin, N.; van der Laan, K.; Groot, M.-L.; van Osch, G.; van Zuijlen, P. Structural and mechanical comparison of human ear, alar, and septal cartilage. Plast. Reconstr. Surg. Glob. Open 2018, 6. [CrossRef] [PubMed]

28. Giretová, M.; Medvecký, L'.; Petrovová, E.; Čížková, D.; Mudroňová, D.; Danko, J. Effects of cell seeding methods on chondrogenic differentiation of rat mesenchymal stem cells in polyhydroxybutyrate/chitosan scaffolds. FOLIA 2019, 63, 6-16.

29. Frisch, J.; Venkatesan, J.K.; Rey-Rico, A.; Madry, H.; Cucchiarini, M. Current progress in stem cell-based gene therapy for articular cartilage repair. Curr. Stem Cell Res. Ther. 2015, 10, 121-131. [CrossRef] [PubMed]

30. Link, J.M.; Salinas, E.Y.; Hu, J.C.; Athanasiou, K.A. The tribology of cartilage: Mechanisms, experimental techniques, and relevance to translational tissue engineering. Clin. Biomech. 2020, 79, 104880. [CrossRef]

31. Liao, J.; Shi, K.; Ding, Q.; Qu, Y.; Luo, F.; Qian, Z. Recent developments in scaffold-guided cartilage tissue regeneration. J. Biomed. Nanotechnol. 2014, 10, 3085-3104. [CrossRef]

32. Roseti, L.; Desando, G.; Cavallo, C.; Petretta, M.; Grigolo, B. Articular cartilage regeneration in osteoarthritis. Cells 2019, 8, 1305. [CrossRef] [PubMed]

33. Jeznach, O.; Kołbuk, D.; Sajkiewicz, P. Injectable hydrogels and nanocomposite hydrogels for cartilage regeneration. J. Biomed. Mater. Res. Part A 2018, 106, 2762-2776. [CrossRef]

34. Ondresik, M.; Azevedo Maia, F.R.; da Silva Morais, A.; Gertrudes, A.C.; Dias Bacelar, A.H.; Correia, C.; Goncalves, C.; Radhouani, H.; Amandi Sousa, R.; Oliveira, J.M. Management of knee osteoarthritis. Current status and future trends. Biotechnol. Bioeng. 2017, 114, 717-739. [CrossRef] 
35. Kwon, J.S.; Yoon, S.M.; Kwon, D.Y.; Tai, G.Z.; Jin, L.M.; Song, B.; Lee, B.; Kim, J.H.; Han, D.K.; Min, B.H. Injectable in situ-forming hydrogel for cartilage tissue engineering. J. Mater. Chem. B 2013, 1, 3314-3321. [CrossRef] [PubMed]

36. Zhang, X.; Li, Z.; Yang, P.; Duan, G.; Liu, X.; Gu, Z.; Li, Y. Polyphenol scaffolds in tissue engineering. Mater. Horiz. 2021, 8, 145-167. [CrossRef]

37. Zou, Y.; Zhang, L.; Yang, L.; Zhu, F.; Ding, M.; Lin, F.; Wang, Z.; Li, Y. “Click” chemistry in polymeric scaffolds: Bioactive materials for tissue engineering. J. Control. Release 2018, 273, 160-179. [CrossRef]

38. Xiao, Y.; Friis, E.A.; Gehrke, S.H.; Detamore, M.S. Mechanical testing of hydrogels in cartilage tissue engineering: Beyond the compressive modulus. Tissue Eng. Part B: Rev. 2013, 19, 403-412. [CrossRef]

39. Vyas, C.; Mishbak, H.; Cooper, G.; Peach, C.; Pereira, R.F.; Bartolo, P. Biological perspectives and current biofabrication strategies in osteochondral tissue engineering. Biomanufacturing Rev. 2020, 5, 1-24. [CrossRef]

40. Zhang, Y.S.; Khademhosseini, A. Advances in engineering hydrogels. Science 2017, 356, 434-437. [CrossRef]

41. Chai, Q.; Jiao, Y.; Yu, X. Hydrogels for biomedical applications: Their characteristics and the mechanisms behind them. Gels 2017, 3, 6. [CrossRef]

42. Sivashanmugam, A.; Kumar, R.A.; Priya, M.V.; Nair, S.V.; Jayakumar, R. An overview of injectable polymeric hydrogels for tissue engineering. Eur. Polym. J. 2015, 72, 543-565. [CrossRef]

43. Lee, S.; Choi, J.H.; Park, A.; Rim, M.; Youn, J.; Lee, W.; Song, J.E.; Khang, G. Advanced gellan gum-based glycol chitosan hydrogel for cartilage tissue engineering biomaterial. Int. J. Biol. Macromol. 2020, 158, 452-460. [CrossRef] [PubMed]

44. Sadeghianmaryan, A.; Naghieh, S.; Sardroud, H.A.; Yazdanpanah, Z.; Soltani, Y.A.; Sernaglia, J.; Chen, X. Extrusion-based printing of chitosan scaffolds and their in vitro characterization for cartilage tissue engineering. Int. J. Biol. Macromol. 2020, 164, 3179-3192. [CrossRef]

45. Yu, R.; Zhang, Y.; Barboiu, M.; Maumus, M.; Noël, D.; Jorgensen, C.; Li, S. Biobased pH-responsive and self-healing hydrogels prepared from O-carboxymethyl chitosan and a 3-dimensional dynamer as cartilage engineering scaffold. Carbohydr. Polym. 2020, 244, 116471. [CrossRef]

46. Li, H.; Chen, R.; Jia, Z.; Wang, C.; Xu, Y.; Li, C.; Xia, H.; Meng, D. Porous fish collagen for cartilage tissue engineering. Am. J. Transl. Res. 2020, 12, 6107.

47. Mirtaghavi, A.; Baldwin, A.; Tanideh, N.; Zarei, M.; Muthuraj, R.; Cao, Y.; Zhao, G.; Geng, J.; Jin, H.; Luo, J. Crosslinked porous three-dimensional cellulose nanofibers-gelatine biocomposite scaffolds for tissue regeneration. Int. J. Biol. Macromol. 2020, 164, 1949-1959. [CrossRef]

48. Nawaz, H.A.; Schröck, K.; Schmid, M.; Krieghoff, J.; Maqsood, I.; Kascholke, C.; Kohn-Polster, C.; Schulz-Siegmund, M.; Hacker, M.C. Injectable oligomer-cross-linked gelatine hydrogels via anhydride-amine-conjugation. J. Mater. Chem. B 2021, 9, $2295-2307$. [CrossRef]

49. Park, H.; Lee, H.J.; An, H.; Lee, K.Y. Alginate hydrogels modified with low molecular weight hyaluronate for cartilage regeneration. Carbohydr. Polym. 2017, 162, 100-107. [CrossRef]

50. Fenn, S.L.; Oldinski, R.A. Visible light crosslinking of methacrylated hyaluronan hydrogels for injectable tissue repair. J. Biomed. Mater. Res. Part B: Appl. Biomater. 2016, 104, 1229-1236. [CrossRef] [PubMed]

51. Tiwari, S.; Bahadur, P. Modified hyaluronic acid based materials for biomedical applications. Int. J. Biol. Macromol. 2019, 121, 556-571. [CrossRef]

52. He, C.; Ji, H.; Qian, Y.; Wang, Q.; Liu, X.; Zhao, W.; Zhao, C. Heparin-based and heparin-inspired hydrogels: Size-effect, gelation and biomedical applications. J. Mater. Chem. B 2019, 7, 1186-1208. [CrossRef]

53. Sim, H.J.; Thambi, T.; Lee, D.S. Heparin-based temperature-sensitive injectable hydrogels for protein delivery. J. Mater. Chem. $B$ 2015, 3, 8892-8901. [CrossRef]

54. Aisenbrey, E.A.; Bryant, S.J. The role of chondroitin sulfate in regulating hypertrophy during MSC chondrogenesis in a cartilage mimetic hydrogel under dynamic loading. Biomaterials 2019, 190, 51-62. [CrossRef]

55. Wang, J.; Zhang, F.; Tsang, W.P.; Wan, C.; Wu, C. Fabrication of injectable high strength hydrogel based on 4-arm star PEG for cartilage tissue engineering. Biomaterials 2017, 120, 11-21. [CrossRef] [PubMed]

56. Mori, H.; Hara, M. Clusters of neural stem/progenitor cells cultured on a soft poly (vinyl alcohol) hydrogel crosslinked by gamma irradiation. J. Biosci. Bioeng. 2016, 121, 584-590. [CrossRef]

57. Li, L.; Yu, F.; Zheng, L.; Wang, R.; Yan, W.; Wang, Z.; Xu, J.; Wu, J.; Shi, D.; Zhu, L. Natural hydrogels for cartilage regeneration: Modification, preparation and application. J. Orthop. Transl. 2019, 17, 26-41. [CrossRef] [PubMed]

58. Dehghan-Baniani, D.; Chen, Y.; Wang, D.; Bagheri, R.; Solouk, A.; Wu, H. Injectable in situ forming kartogenin-loaded chitosan hydrogel with tunable rheological properties for cartilage tissue engineering. Colloids Surf. B: Biointerfaces 2020, $192,111059$. [CrossRef]

59. Kolanthai, E.; Sindu, P.A.; Khajuria, D.K.; Veerla, S.C.; Kuppuswamy, D.; Catalani, L.H.; Mahapatra, D.R. Graphene oxide-a tool for the preparation of chemically crosslinking free alginate-chitosan-collagen scaffolds for bone tissue engineering. ACS Appl. Mater. Interfaces 2018, 10, 12441-12452. [CrossRef] [PubMed]

60. Park, H.; Choi, B.; Hu, J.; Lee, M. Injectable chitosan hyaluronic acid hydrogels for cartilage tissue engineering. Acta Biomater. 2013, 9, 4779-4786. [CrossRef]

61. Kashi, M.; Baghbani, F.; Moztarzadeh, F.; Mobasheri, H.; Kowsari, E. Green synthesis of degradable conductive thermosensitive oligopyrrole/chitosan hydrogel intended for cartilage tissue engineering. Int. J. Biol. Macromol. 2018, 107, 1567-1575. [CrossRef] 
62. Piątkowski, M.; Kitala, D.; Radwan-Pragłowska, J.; Janus, Ł.; Klama-Baryła, A.; Łabuś, W.; Tomanek, E.; Glik, J.; Matýsek, D.; Kawecki, M. Chitosan/aminoacid hydrogels with antimicrobial and bioactive properties as new scaffolds for human mesenchymal stem cells culture applicable in wound healing. Express Polym. Lett. 2018, 12, 100-112. [CrossRef]

63. Bang, S.; Jung, U.-W.; Noh, I. Synthesis and biocompatibility characterizations of in situ chondroitin sulfate-gelatin hydrogel for tissue engineering. Tissue Eng. Regen. Med. 2018, 15, 25-35. [CrossRef]

64. Dai, M.; Sui, B.; Hua, Y.; Zhang, Y.; Bao, B.; Lin, Q.; Liu, X.; Zhu, L.; Sun, J. A well defect-suitable and high-strength biomimetic squid type II gelatin hydrogel promoted in situ costal cartilage regeneration via dynamic immunomodulation and direct induction manners. Biomaterials 2020, 240, 119841. [CrossRef]

65. Fernandez, J.G.; Seetharam, S.; Ding, C.; Feliz, J.; Doherty, E.; Ingber, D.E. Direct bonding of chitosan biomaterials to tissues using transglutaminase for surgical repair or device implantation. Tissue Eng. Part A 2017, 23, 135-142. [CrossRef]

66. Kontturi, L.-S.; Järvinen, E.; Muhonen, V.; Collin, E.C.; Pandit, A.S.; Kiviranta, I.; Yliperttula, M.; Urtti, A. An injectable, in situ forming type II collagen/hyaluronic acid hydrogel vehicle for chondrocyte delivery in cartilage tissue engineering. Drug Deliv. Transl. Res. 2014, 4, 149-158. [CrossRef]

67. Zeng, L.; Yao, Y.; Wang, D.-A.; Chen, X. Effect of microcavitary alginate hydrogel with different pore sizes on chondrocyte culture for cartilage tissue engineering. Mater. Sci. Eng. C 2014, 34, 168-175. [CrossRef] [PubMed]

68. Zheng, X.; Zhang, Q.; Liu, J.; Pei, Y.; Tang, K. A unique high mechanical strength dialdehyde microfibrillated cellulose/gelatin composite hydrogel with a giant network structure. RSC Adv. 2016, 6, 71999-72007. [CrossRef]

69. Heo, J.; Koh, R.H.; Shim, W.; Kim, H.D.; Yim, H.-G.; Hwang, N.S. Riboflavin-induced photo-crosslinking of collagen hydrogel and its application in meniscus tissue engineering. Drug Deliv. Transl. Res. 2016, 6, 148-158. [CrossRef]

70. Oh, B.H.; Bismarck, A.; Chan-Park, M.B. Injectable, Interconnected, High-Porosity Macroporous Biocompatible Gelatin Scaffolds Made by Surfactant-Free Emulsion Templating. Macromol. Rapid Commun. 2015, 36, 364-372. [CrossRef]

71. Balakrishnan, B.; Joshi, N.; Jayakrishnan, A.; Banerjee, R. Self-crosslinked oxidized alginate/gelatin hydrogel as injectable, adhesive biomimetic scaffolds for cartilage regeneration. Acta Biomater. 2014, 10, 3650-3663. [CrossRef] [PubMed]

72. Antich, C.; de Vicente, J.; Jiménez, G.; Chocarro, C.; Carrillo, E.; Montañez, E.; Gálvez-Martín, P.; Marchal, J.A. Bio-inspired hydrogel composed of hyaluronic acid and alginate as a potential bioink for 3D bioprinting of articular cartilage engineering constructs. Acta Biomater. 2020, 106, 114-123. [CrossRef]

73. Chen, F.; Ni, Y.; Liu, B.; Zhou, T.; Yu, C.; Su, Y.; Zhu, X.; Yu, X.; Zhou, Y. Self-crosslinking and injectable hyaluronic acid/RGDfunctionalized pectin hydrogel for cartilage tissue engineering. Carbohydr. Polym. 2017, 166, 31-44. [CrossRef]

74. Domingues, R.M.; Silva, M.; Gershovich, P.; Betta, S.; Babo, P.; Caridade, S.G.; Mano, J.O.F.; Motta, A.; Reis, R.L.; Gomes, M.E. Development of injectable hyaluronic acid/cellulose nanocrystals bionanocomposite hydrogels for tissue engineering applications. Bioconjugate Chem. 2015, 26, 1571-1581. [CrossRef] [PubMed]

75. Feng, Q.; Lin, S.; Zhang, K.; Dong, C.; Wu, T.; Huang, H.; Yan, X.; Zhang, L.; Li, G.; Bian, L. Sulfated hyaluronic acid hydrogels with retarded degradation and enhanced growth factor retention promote hMSC chondrogenesis and articular cartilage integrity with reduced hypertrophy. Acta Biomater. 2017, 53, 329-342. [CrossRef] [PubMed]

76. La Gatta, A.; Ricci, G.; Stellavato, A.; Cammarota, M.; Filosa, R.; Papa, A.; D’Agostino, A.; Portaccio, M.; Delfino, I.; De Rosa, M. Hyaluronan hydrogels with a low degree of modification as scaffolds for cartilage engineering. Int. J. Biol. Macromol. 2017, 103, 978-989. [CrossRef]

77. Mikael, P.E.; Kim, H.S.; Nukavarapu, S.P. Hybrid extracellular matrix design for cartilage-mediated bone regeneration. J. Biomed. Mater. Res. Part B: Appl. Biomater. 2018, 106, 300-309. [CrossRef]

78. Palumbo, F.S.; Fiorica, C.; Di Stefano, M.; Pitarresi, G.; Gulino, A.; Agnello, S.; Giammona, G. In situ forming hydrogels of hyaluronic acid and inulin derivatives for cartilage regeneration. Carbohydr. Polym. 2015, 122, 408-416. [CrossRef] [PubMed]

79. Cavalli, E.; Levinson, C.; Hertl, M.; Broguiere, N.; Brück, O.; Mustjoki, S.; Gerstenberg, A.; Weber, D.; Salzmann, G.; Steinwachs, M. Characterization of polydactyly chondrocytes and their use in cartilage engineering. Sci. Rep. 2019, 9, 1-15.

80. Broguiere, N.; Cavalli, E.; Salzmann, G.M.; Applegate, L.A.; Zenobi-Wong, M. Factor XIII cross-linked hyaluronan hydrogels for cartilage tissue engineering. ACS Biomater. Sci. Eng. 2016, 2, 2176-2184. [CrossRef]

81. Yu, F.; Cao, X.; Li, Y.; Zeng, L.; Zhu, J.; Wang, G.; Chen, X. Diels-Alder crosslinked HA/PEG hydrogels with high elasticity and fatigue resistance for cell encapsulation and articular cartilage tissue repair. Polym. Chem. 2014, 5, 5116-5123. [CrossRef]

82. Almeida, H.; Eswaramoorthy, R.; Cunniffe, G.; Buckley, C.; O’Brien, F.; Kelly, D. Fibrin hydrogels functionalized with cartilage extracellular matrix and incorporating freshly isolated stromal cells as an injectable for cartilage regeneration. Acta Biomater. 2016, 36, 55-62. [CrossRef]

83. Benavides, O.M.; Quinn, J.P.; Pok, S.; Petsche Connell, J.; Ruano, R.; Jacot, J.G. Capillary-like network formation by human amniotic fluid-derived stem cells within fibrin/poly (ethylene glycol) hydrogels. Tissue Eng. Part A 2015, 21, 1185-1194. [CrossRef] [PubMed]

84. Rial, R.; Liu, Z.; Ruso, J.M. Soft actuated hybrid hydrogel with bioinspired complexity to control mechanical flexure behavior for tissue engineering. Nanomaterials 2020, 10, 1302. [CrossRef]

85. You, F.; Chen, X.; Cooper, D.; Chang, T.; Eames, B.F. Homogeneous hydroxyapatite/alginate composite hydrogel promotes calcified cartilage matrix deposition with potential for three-dimensional bioprinting. Biofabrication 2018, 11, 015015. [CrossRef] 
86. Critchley, S.; Cunniffe, G.; O’Reilly, A.; Diaz-Payno, P.; Schipani, R.; McAlinden, A.; Withers, D.; Shin, J.; Alsberg, E.; Kelly, D.J. Regeneration of osteochondral defects using developmentally inspired cartilaginous templates. Tissue Eng. Part A 2019, 25, 159-171. [CrossRef]

87. Zhu, D.; Wang, H.; Trinh, P.; Heilshorn, S.C.; Yang, F. Elastin-like protein-hyaluronic acid (ELP-HA) hydrogels with decoupled mechanical and biochemical cues for cartilage regeneration. Biomaterials 2017, 127, 132-140. [CrossRef]

88. Khorshidi, S.; Karkhaneh, A. A self-crosslinking tri-component hydrogel based on functionalized polysaccharides and gelatin for tissue engineering applications. Mater. Lett. 2016, 164, 468-471. [CrossRef]

89. Jaikumar, D.; Sajesh, K.; Soumya, S.; Nimal, T.; Chennazhi, K.; Nair, S.V.; Jayakumar, R. Injectable alginate-O-carboxymethyl chitosan/nano fibrin composite hydrogels for adipose tissue engineering. Int. J. Biol. Macromol. 2015, 74, 318-326. [CrossRef]

90. Fathi, A.; Mithieux, S.M.; Wei, H.; Chrzanowski, W.; Valtchev, P.; Weiss, A.S.; Dehghani, F. Elastin based cell-laden injectable hydrogels with tunable gelation, mechanical and biodegradation properties. Biomaterials 2014, 35, 5425-5435. [CrossRef]

91. Cipriani, F.; Krüger, M.; De Torre, I.G.; Sierra, L.Q.; Rodrigo, M.A.; Kock, L.; Rodriguez-Cabello, J.C. Cartilage regeneration in preannealed silk elastin-like co-recombinamers injectable hydrogel embedded with mature chondrocytes in an ex vivo culture platform. Biomacromolecules 2018, 19, 4333-4347. [CrossRef] [PubMed]

92. Chen, F.; Yu, S.; Liu, B.; Ni, Y.; Yu, C.; Su, Y.; Zhu, X.; Yu, X.; Zhou, Y.; Yan, D. An injectable enzymatically crosslinked carboxymethylated pullulan/chondroitin sulfate hydrogel for cartilage tissue engineering. Sci. Rep. 2016, 6, 1-12.

93. Wiltsey, C.; Kubinski, P.; Christiani, T.; Toomer, K.; Sheehan, J.; Branda, A.; Kadlowec, J.; Iftode, C.; Vernengo, J. Characterization of injectable hydrogels based on poly (N-isopropylacrylamide)-g-chondroitin sulfate with adhesive properties for nucleus pulposus tissue engineering. J. Mater. Sci. Mater. Med. 2013, 24, 837-847. [CrossRef]

94. Paul, A.; Manoharan, V.; Krafft, D.; Assmann, A.; Uquillas, J.A.; Shin, S.R.; Hasan, A.; Hussain, M.A.; Memic, A.; Gaharwar, A.K. Nanoengineered biomimetic hydrogels for guiding human stem cell osteogenesis in three dimensional microenvironments. J. Mater. Chem. B 2016, 4, 3544-3554. [CrossRef] [PubMed]

95. Leppiniemi, J.; Lahtinen, P.; Paajanen, A.; Mahlberg, R.; Metsä-Kortelainen, S.; Pinomaa, T.; Pajari, H.; Vikholm-Lundin, I.; Pursula, P.; Hytönen, V.P. 3D-printable bioactivated nanocellulose-alginate hydrogels. ACS Appl. Mater. Interfaces 2017, 9, 21959-21970. [CrossRef]

96. Li, S.; Wang, L.; Yu, X.; Wang, C.; Wang, Z. Synthesis and characterization of a novel double cross-linked hydrogel based on Diels-Alder click reaction and coordination bonding. Mater. Sci. Eng. C 2018, 82, 299-309. [CrossRef]

97. Mehrali, M.; Thakur, A.; Pennisi, C.P.; Talebian, S.; Arpanaei, A.; Nikkhah, M.; Dolatshahi-Pirouz, A. Nanoreinforced hydrogels for tissue engineering: Biomaterials that are compatible with load-bearing and electroactive tissues. Adv. Mater. 2017, 29, 1603612 [CrossRef] [PubMed]

98. Visser, J.; Peters, B.; Burger, T.J.; Boomstra, J.; Dhert, W.J.; Melchels, F.P.; Malda, J. Biofabrication of multi-material anatomically shaped tissue constructs. Biofabrication 2013, 5, 035007. [CrossRef]

99. Rodell, C.B.; Mealy, J.E.; Burdick, J.A. Supramolecular guest-host interactions for the preparation of biomedical materials. Bioconjugate Chem. 2015, 26, 2279-2289. [CrossRef]

100. Yang, L.; Tan, X.; Wang, Z.; Zhang, X. Supramolecular polymers: Historical development, preparation, characterization, and functions. Chem. Rev. 2015, 115, 7196-7239. [CrossRef]

101. Li, H.; Wang, H.; Zhang, D.; Xu, Z.; Liu, W. A highly tough and stiff supramolecular polymer double network hydrogel. Polymer 2018, 153, 193-200. [CrossRef]

102. Mihajlovic, M.; Mihajlovic, M.; Dankers, P.Y.; Masereeuw, R.; Sijbesma, R.P. Carbon nanotube reinforced supramolecular hydrogels for bioapplications. Macromol. Biosci. 2019, 19, 1800173. [CrossRef] [PubMed]

103. Yu, X.; Yang, P.; Zhang, Z.; Wang, L.; Liu, L.; Wang, Y. Self-healing polyurethane nanocomposite films with recoverable surface hydrophobicity. J. Appl. Polym. Sci. 2018, 135, 46421. [CrossRef]

104. Teng, L.; Chen, Y.; Jia, Y.-G.; Ren, L. Supramolecular and dynamic covalent hydrogel scaffolds: From gelation chemistry to enhanced cell retention and cartilage regeneration. J. Mater. Chem. B 2019, 7, 6705-6736. [CrossRef]

105. Jeong, S.H.; Kim, M.; Kim, T.Y.; Kim, H.; Ju, J.H.; Hahn, S.K. Supramolecular Injectable Hyaluronate Hydrogels for Cartilage Tissue Regeneration. ACS Appl. Bio Mater. 2020, 3, 5040-5047. [CrossRef]

106. Jaiswal, M.K.; Xavier, J.R.; Carrow, J.K.; Desai, P.; Alge, D.; Gaharwar, A.K. Mechanically stiff nanocomposite hydrogels at ultralow nanoparticle content. ACS Nano 2016, 10, 246-256. [CrossRef]

107. Asadi, N.; Alizadeh, E.; Salehi, R.; Khalandi, B.; Davaran, S.; Akbarzadeh, A. Nanocomposite hydrogels for cartilage tissue engineering: A review. Artif. Cells Nanomed. Biotechnol. 2018, 46, 465-471. [CrossRef] [PubMed]

108. Zhao, H.; Liu, M.; Zhang, Y.; Yin, J.; Pei, R. Nanocomposite hydrogels for tissue engineering applications. Nanoscale 2020, 12, 14976-14995. [CrossRef]

109. Piluso, S.; Labet, M.; Zhou, C.; Seo, J.W.; Thielemans, W.; Patterson, J. Engineered three-dimensional microenvironments with starch nanocrystals as cell-instructive materials. Biomacromolecules 2019, 20, 3819-3830. [CrossRef]

110. Asadi, N.; Alizadeh, E.; Rahmani Del Bakhshayesh, A.; Mostafavi, E.; Akbarzadeh, A.; Davaran, S. Fabrication and in vitro evaluation of Nanocomposite hydrogel scaffolds based on gelatin/PCL-PEG-PCL for cartilage tissue engineering. ACS Omega 2019, 4, 449-457. [CrossRef] 
111. Bonhome-Espinosa, A.B.; Campos, F.; Durand-Herrera, D.; Sánchez-López, J.D.; Schaub, S.; Durán, J.D.; Lopez-Lopez, M.T.; Carriel, V. In vitro characterization of a novel magnetic fibrin-agarose hydrogel for cartilage tissue engineering. J. Mech. Behav. Biomed. Mater. 2020, 104, 103619. [CrossRef] [PubMed]

112. Huang, J.; Liang, Y.; Jia, Z.; Chen, J.; Duan, L.; Liu, W.; Zhu, F.; Liang, Q.; Zhu, W.; You, W. Development of magnetic nanocomposite hydrogel with potential cartilage tissue engineering. ACS Omega 2018, 3, 6182-6189. [CrossRef]

113. Nejadnik, M.R.; Yang, X.; Bongio, M.; Alghamdi, H.S.; Van den Beucken, J.J.; Huysmans, M.C.; Jansen, J.A.; Hilborn, J.; Ossipov, D.; Leeuwenburgh, S.C. Self-healing hybrid nanocomposites consisting of bisphosphonated hyaluronan and calcium phosphate nanoparticles. Biomaterials 2014, 35, 6918-6929. [CrossRef]

114. Schlichting, K.E.; Copeland-Johnson, T.M.; Goodman, M.; Lipert, R.J.; Prozorov, T.; Liu, X.; McKinley, T.O.; Lin, Z.; Martin, J.A.; Mallapragada, S.K. Synthesis of a novel photopolymerized nanocomposite hydrogel for treatment of acute mechanical damage to cartilage. Acta Biomater. 2011, 7, 3094-3100. [CrossRef] [PubMed]

115. Wang, Y.; Yu, H.; Yang, H.; Hao, X.; Tang, Q.; Zhang, X. An Injectable Interpenetrating Polymer Network Hydrogel with Tunable Mechanical Properties and Self-Healing Abilities. Macromol. Chem. Phys. 2017, 218, 1700348. [CrossRef]

116. Hu, M.; Yang, J.; Xu, J. Structural and biological investigation of chitosan/hyaluronic acid with silanized-hydroxypropyl methylcellulose as an injectable reinforced interpenetrating network hydrogel for cartilage tissue engineering. Drug Deliv. 2021, 28, 607-619. [CrossRef] [PubMed]

117. Schipani, R.; Scheurer, S.; Florentin, R.; Critchley, S.E.; Kelly, D.J. Reinforcing interpenetrating network hydrogels with 3D printed polymer networks to engineer cartilage mimetic composites. Biofabrication 2020, 12, 035011. [CrossRef] [PubMed]

118. Farooqi, A.R.; Zimmermann, J.; Bader, R.; van Rienen, U. Numerical simulation of electroactive hydrogels for cartilage-tissue engineering. Materials 2019, 12, 2913. [CrossRef]

119. Davoodi, P.; Lee, L.Y.; Xu, Q.; Sunil, V.; Sun, Y.; Soh, S.; Wang, C.-H. Drug delivery systems for programmed and on-demand release. Adv. Drug Deliv. Rev. 2018, 132, 104-138. [CrossRef]

120. Mohamed, M.A.; Fallahi, A.; El-Sokkary, A.M.; Salehi, S.; Akl, M.A.; Jafari, A.; Tamayol, A.; Fenniri, H.; Khademhosseini, A.; Andreadis, S.T. Stimuli-responsive hydrogels for manipulation of cell microenvironment: From chemistry to biofabrication technology. Prog. Polym. Sci. 2019, 98, 101147. [CrossRef]

121. Jeong, B.; Kim, S.W.; Bae, Y.H. Thermosensitive sol-gel reversible hydrogels. Adv. Drug Deliv. Rev. 2012, 64, 154-162. [CrossRef]

122. Klouda, L.; Mikos, A.G. Thermoresponsive hydrogels in biomedical applications. Eur. J. Pharm. Biopharm. 2008, 68, 34-45. [CrossRef]

123. Brudno, Y.; Mooney, D.J. On-demand drug delivery from local depots. J. Control. Release 2015, 219, 8-17. [CrossRef]

124. Gandavarapu, N.R.; Azagarsamy, M.A.; Anseth, K.S. Photo-click living strategy for controlled, reversible exchange of biochemical ligands. Adv. Mater. 2014, 26, 2521-2526. [CrossRef] [PubMed]

125. Olejniczak, J.; Carling, C.-J.; Almutairi, A. Photocontrolled release using one-photon absorption of visible or NIR light. J. Control. Release 2015, 219, 18-30. [CrossRef]

126. Tomatsu, I.; Peng, K.; Kros, A. Photoresponsive hydrogels for biomedical applications. Adv. Drug Deliv. Rev. 2011, 63, 1257-1266. [CrossRef]

127. Salehi, M.; Naseri-Nosar, M.; Azami, M.; Nodooshan, S.J.; Arish, J. Comparative study of poly (L-lactic acid) scaffolds coated with chitosan nanoparticles prepared via ultrasonication and ionic gelation techniques. Tissue Eng. Regen. Med. 2016, 13, 498-506. [CrossRef]

128. Karimi, F.; Collins, J.; Heath, D.E.; Connal, L.A. Dynamic covalent hydrogels for triggered cell capture and release. Bioconjugate Chem. 2017, 28, 2235-2240. [CrossRef] [PubMed]

129. Zhang, S.; Bellinger, A.M.; Glettig, D.L.; Barman, R.; Lee, Y.-A.L.; Zhu, J.; Cleveland, C.; Montgomery, V.A.; Gu, L.; Nash, L.D. A pH-responsive supramolecular polymer gel as an enteric elastomer for use in gastric devices. Nat. Mater. 2015, 14, 1065-1071. [CrossRef]

130. Yang, J.-A.; Yeom, J.; Hwang, B.W.; Hoffman, A.S.; Hahn, S.K. In situ-forming injectable hydrogels for regenerative medicine. Prog. Polym. Sci. 2014, 39, 1973-1986. [CrossRef]

131. Davoodi, P.; Srinivasan, M.P.; Wang, C.-H. Synthesis of intracellular reduction-sensitive amphiphilic polyethyleneimine and poly ( $\varepsilon$-caprolactone) graft copolymer for on-demand release of doxorubicin and p53 plasmid DNA. Acta Biomater. 2016, 39, 79-93. [CrossRef] [PubMed]

132. Skaalure, S.C.; Chu, S.; Bryant, S.J. An enzyme-sensitive PEG hydrogel based on aggrecan catabolism for cartilage tissue engineering. Adv. Healthc. Mater. 2015, 4, 420-431. [CrossRef] [PubMed]

133. Moon, H.J.; Park, M.H.; Joo, M.K.; Jeong, B. Temperature-responsive compounds as in situ gelling biomedical materials. Chem. Soc. Rev. 2012, 41, 4860-4883. [CrossRef]

134. Ruel-Gariepy, E.; Leroux, J.-C. In situ-forming hydrogels—review of temperature-sensitive systems. Eur. J. Pharm. Biopharm. 2004, 58, 409-426. [CrossRef]

135. Sá-Lima, H.; Tuzlakoglu, K.; Mano, J.F.; Reis, R.L. Thermoresponsive poly (N-isopropylacrylamide)-g-methylcellulose hydrogel as a three-dimensional extracellular matrix for cartilage-engineered applications. J. Biomed. Mater. Res. Part A 2011, 98, 596-603. [CrossRef]

136. Park, K.M.; Lee, S.Y.; Joung, Y.K.; Na, J.S.; Lee, M.C.; Park, K.D. Thermosensitive chitosan-Pluronic hydrogel as an injectable cell delivery carrier for cartilage regeneration. Acta Biomater. 2009, 5, 1956-1965. [CrossRef] 
137. Abbadessa, A.; Mouser, V.H.; Blokzijl, M.M.; Gawlitta, D.; Dhert, W.J.; Hennink, W.E.; Malda, J.; Vermonden, T. A synthetic thermosensitive hydrogel for cartilage bioprinting and its biofunctionalization with polysaccharides. Biomacromolecules 2016, 17, 2137-2147. [CrossRef] [PubMed]

138. Strehin, I.; Nahas, Z.; Arora, K.; Nguyen, T.; Elisseeff, J. A versatile pH sensitive chondroitin sulfate-PEG tissue adhesive and hydrogel. Biomaterials 2010, 31, 2788-2797. [CrossRef]

139. Halacheva, S.S.; Freemont, T.J.; Saunders, B.R. pH-responsive physical gels from poly (meth) acrylic acid-containing crosslinked particles: The relationship between structure and mechanical properties. J. Mater. Chem. B 2013, 1, 4065-4078. [CrossRef] [PubMed]

140. Sá-Lima, H.; Caridade, S.G.; Mano, J.F.; Reis, R.L. Stimuli-responsive chitosan-starch injectable hydrogels combined with encapsulated adipose-derived stromal cells for articular cartilage regeneration. Soft Matter 2010, 6, 5184-5195. [CrossRef]

141. Levett, P.A.; Melchels, F.P.; Schrobback, K.; Hutmacher, D.W.; Malda, J.; Klein, T.J. A biomimetic extracellular matrix for cartilage tissue engineering centered on photocurable gelatin, hyaluronic acid and chondroitin sulfate. Acta Biomater. 2014, 10, 214-223. [CrossRef]

142. Giammanco, G.E.; Carrion, B.; Coleman, R.M.; Ostrowski, A.D. Photoresponsive polysaccharide-based hydrogels with tunable mechanical properties for cartilage tissue engineering. ACS Appl. Mater. Interfaces 2016, 8, 14423-14429. [CrossRef]

143. Jin, R.; Teixeira, L.M.; Dijkstra, P.J.; Karperien, M.; Van Blitterswijk, C.; Zhong, Z.; Feijen, J. Injectable chitosan-based hydrogels for cartilage tissue engineering. Biomaterials 2009, 30, 2544-2551. [CrossRef] [PubMed]

144. Xie, J.; Chen, K.; Huang, J.; Lee, S.; Wang, J.; Gao, J.; Li, X.; Chen, X. PET/NIRF/MRI triple functional iron oxide nanoparticles. Biomaterials 2010, 31, 3016-3022. [CrossRef] [PubMed]

145. Ogushi, Y.; Sakai, S.; Kawakami, K. Synthesis of enzymatically-gellable carboxymethylcellulose for biomedical applications. J. Biosci. Bioeng. 2007, 104, 30-33. [CrossRef]

146. Ruiz-Cantu, L.; Gleadall, A.; Faris, C.; Segal, J.; Shakesheff, K.; Yang, J. Multi-material 3D bioprinting of porous constructs for cartilage regeneration. Mater. Sci. Eng. C 2020, 109, 110578. [CrossRef] [PubMed]

147. Kang, H.-W.; Lee, S.J.; Ko, I.K.; Kengla, C.; Yoo, J.J.; Atala, A. A 3D bioprinting system to produce human-scale tissue constructs with structural integrity. Nat. Biotechnol. 2016, 34, 312-319. [CrossRef]

148. Pourbashir, S.; Shahrousvand, M.; Ghaffari, M. Preparation and characterization of semi-IPNs of polycaprolactone/poly (acrylic acid)/cellulosic nanowhisker as artificial articular cartilage. Int. J. Biol. Macromol. 2020, 142, 298-310. [CrossRef]

149. Dang-i, A.Y.; Kousar, A.; Liu, J.; Mukwaya, V.; Zhao, C.; Wang, F.; Hou, L.; Feng, C.-L. Mechanically stable C2-phenylalanine hybrid hydrogels for manipulating cell adhesion. ACS Appl. Mater. Interfaces 2019, 11, 28657-28664. [CrossRef]

150. Luo, X.B.; Ma, M.F.; Zhou, X.J. Hydroxyapatite-poly (vinyl alcohol)-sodium Alginate Porous Hydrogels with Poly (vinyl alcohol) Surface Layer Used for Articular Cartilage Repair. Proc. Mater. Sci. Forum 2016, 852, 1155-1161. [CrossRef]

151. Chen, J.X.; Cao, L.J.; Shi, Y.; Wang, P.; Chen, J.H. In situ supramolecular hydrogel based on hyaluronic acid and dextran derivatives as cell scaffold. J. Biomed. Mater. Res. Part A 2016, 104, 2263-2270. [CrossRef]

152. Dinescu, S.; Galateanu, B.; Radu, E.; Hermenean, A.; Lungu, A.; Stancu, I.C.; Jianu, D.; Tumbar, T.; Costache, M. A 3D porous gelatin-alginate-based-IPN acts as an efficient promoter of chondrogenesis from human adipose-derived stem cells. Stem Cells Int. 2015, 2015, 252909. [CrossRef] [PubMed]

153. Pirinen, S.; Karvinen, J.; Tiitu, V.; Suvanto, M.; Pakkanen, T.T. Control of swelling properties of polyvinyl alcohol/hyaluronic acid hydrogels for the encapsulation of chondrocyte cells. J. Appl. Polym. Sci. 2015, 132, 42272. [CrossRef]

154. Skaalure, S.C.; Dimson, S.O.; Pennington, A.M.; Bryant, S.J. Semi-interpenetrating networks of hyaluronic acid in degradable PEG hydrogels for cartilage tissue engineering. Acta Biomater. 2014, 10, 3409-3420. [CrossRef]

155. Snyder, T.N.; Madhavan, K.; Intrator, M.; Dregalla, R.C.; Park, D. A fibrin/hyaluronic acid hydrogel for the delivery of mesenchymal stem cells and potential for articular cartilage repair. J. Biol. Eng. 2014, 8, 1-11.

156. Ingavle, G.C.; Frei, A.W.; Gehrke, S.H.; Detamore, M.S. Incorporation of aggrecan in interpenetrating network hydrogels to improve cellular performance for cartilage tissue engineering. Tissue Eng. Part A 2013, 19, 1349-1359. [CrossRef]

157. Wei, K.; Zhu, M.; Sun, Y.; Xu, J.; Feng, Q.; Lin, S.; Wu, T.; Xu, J.; Tian, F.; Xia, J. Robust biopolymeric supramolecular “HostGuest Macromer" hydrogels reinforced by in situ formed multivalent nanoclusters for cartilage regeneration. Macromolecules 2016, 49, 866-875. [CrossRef]

158. Jung, H.; Park, J.S.; Yeom, J.; Selvapalam, N.; Park, K.M.; Oh, K.; Yang, J.-A.; Park, K.H.; Hahn, S.K.; Kim, K. 3D tissue engineered supramolecular hydrogels for controlled chondrogenesis of human mesenchymal stem cells. Biomacromolecules 2014, 15, 707-714. [CrossRef]

159. Saygili, E.; Kaya, E.; Ilhan-Ayisigi, E.; Saglam-Metiner, P.; Alarcin, E.; Kazan, A.; Girgic, E.; Kim, Y.-W.; Gunes, K.; Eren-Ozcan, G.G. An alginate-poly (acrylamide) hydrogel with TGF- $\beta 3$ loaded nanoparticles for cartilage repair: Biodegradability, biocompatibility and protein adsorption. Int. J. Biol. Macromol. 2021, 172, 381-393. [CrossRef] [PubMed]

160. Meng, Y.; Zhao, X.; Ye, L. Construction of Dual Orientation Crystalline Structure in Poly (vinyl alcohol)/Graphene Oxide Nano-Composite Hydrogels and Reinforcing Mechanism. Ind. Eng. Chem. Res. 2019, 58, 10908-10921. [CrossRef]

161. Su, W.; Hu, Y.; Zeng, M.; Li, M.; Lin, S.; Zhou, Y.; Xie, J. Design and evaluation of nano-hydroxyapatite/poly (vinyl alcohol) hydrogels coated with poly (lactic-co-glycolic acid)/nano-hydroxyapatite/poly (vinyl alcohol) scaffolds for cartilage repair. J. Orthop. Surg. Res. 2019, 14, 1-9. [CrossRef] [PubMed] 
162. Boyer, C.; Figueiredo, L.; Pace, R.; Lesoeur, J.; Rouillon, T.; Le Visage, C.; Tassin, J.-F.; Weiss, P.; Guicheux, J.; Rethore, G. Laponite nanoparticle-associated silated hydroxypropylmethyl cellulose as an injectable reinforced interpenetrating network hydrogel for cartilage tissue engineering. Acta Biomater. 2018, 65, 112-122. [CrossRef] [PubMed]

163. Nojoomi, A.; Tamjid, E.; Simchi, A.; Bonakdar, S.; Stroeve, P. Injectable polyethylene glycol-laponite composite hydrogels as articular cartilage scaffolds with superior mechanical and rheological properties. Int. J. Polym. Mater. Polym. Biomater. 2017, 66, 105-114. [CrossRef]

164. Mirahmadi, F.; Tafazzoli-Shadpour, M.; Shokrgozar, M.A.; Bonakdar, S. Enhanced mechanical properties of thermosensitive chitosan hydrogel by silk fibers for cartilage tissue engineering. Mater. Sci. Eng. C 2013, 33, 4786-4794. [CrossRef] [PubMed]

165. Li, Q.; Liu, C.; Wen, J.; Wu, Y.; Shan, Y.; Liao, J. The design, mechanism and biomedical application of self-healing hydrogels. Chin. Chem. Lett. 2017, 28, 1857-1874. [CrossRef]

166. Khan, M.; Koivisto, J.T.; Hukka, T.I.; Hokka, M.; Kellomäki, M. Composite hydrogels using bioinspired approach with in situ fast gelation and self-healing ability as future injectable biomaterial. ACS Appl. Mater. Interfaces 2018, 10, 11950-11960. [CrossRef]

167. Wang, S.; Urban, M.W. Self-healing polymers. Nat. Rev. Mater. 2020, 5, 562-583. [CrossRef]

168. Tu, Y.; Chen, N.; Li, C.; Liu, H.; Zhu, R.; Chen, S.; Xiao, Q.; Liu, J.; Ramakrishna, S.; He, L. Advances in injectable self-healing biomedical hydrogels. Acta Biomater. 2019, 90, 1-20. [CrossRef]

169. Binder, W.H. Self-Healing Polymers: From Principles to Applications; Wiley Online Library: Weinheim, Germany, 2013.

170. Maiz-Fernández, S.; Pérez-Álvarez, L.; Ruiz-Rubio, L.; Vilas-Vilela, J.L.; Lanceros-Mendez, S. Polysaccharide-based in situ self-healing hydrogels for tissue engineering applications. Polymers 2020, 12, 2261. [CrossRef]

171. Leach, J.B.; Bivens, K.A.; Collins, C.N.; Schmidt, C.E. Development of photocrosslinkable hyaluronic acid-polyethylene glycolpeptide composite hydrogels for soft tissue engineering. J. Biomed. Mater. Res. Part A: Off. J. Soc. Biomater. Jpn. Soc. Biomater. Aust. Soc. Biomater. Korean Soc. Biomater. 2004, 70, 74-82. [CrossRef] [PubMed]

172. Raimondo, M.; Guadagno, L. Healing efficiency of epoxy-based materials for structural applications. Polym. Compos. 2013, 34, 1525-1532. [CrossRef]

173. Highley, C.B.; Prestwich, G.D.; Burdick, J.A. Recent advances in hyaluronic acid hydrogels for biomedical applications. Curr. Opin. Biotechnol. 2016, 40, 35-40. [CrossRef]

174. Ding, N.; Cai, X.; Zhang, P.; Dong, S.; Du, B.; Nie, J.; Yu, P. Mimicking the Mechanical Properties of Cartilage Using Ionic-and Hydrogen-Bond Cross-Linked Hydrogels with a High Equilibrium Water Content above 70\%. ACS Appl. Polym. Mater. 2021, 3, 2709-2721. [CrossRef]

175. Jiang, H.; Duan, L.; Ren, X.; Gao, G. Hydrophobic association hydrogels with excellent mechanical and self-healing properties. Eur. Polym. J. 2019, 112, 660-669. [CrossRef]

176. Balakrishnan, B.; Banerjee, R. Biopolymer-based hydrogels for cartilage tissue engineering. Chem. Rev. 2011, 111, 4453-4474. [CrossRef]

177. Roh, H.-H.; Kim, H.-S.; Kim, C.; Lee, K.-Y. 3D Printing of Polysaccharide-Based Self-Healing Hydrogel Reinforced with Alginate for Secondary Cross-Linking. Biomedicines 2021, 9, 1224. [CrossRef]

178. Wang, L.; Zhou, W.; Wang, Q.; Xu, C.; Tang, Q.; Yang, H. An injectable, dual responsive, and self-healing hydrogel based on oxidized sodium alginate and hydrazide-modified poly (ethyleneglycol). Molecules 2018, 23, 546. [CrossRef]

179. Yu, F.; Cao, X.; Du, J.; Wang, G.; Chen, X. Multifunctional hydrogel with good structure integrity, self-healing, and tissueadhesive property formed by combining Diels-Alder click reaction and acylhydrazone bond. ACS Appl. Mater. Interfaces 2015, 7, 24023-24031. [CrossRef]

180. Wypych, G. Self-Healing Materials; Elsevier: Amsterdam, The Netherlands, 2019.

181. Döhler, D.; Michael, P.; Binder, W. Principles of Self-Healing Polymers. In Self-Healing Polymers; Wiley Online Library: Hoboken, NJ, USA, 2013; pp. 5-60.

182. Ferreira, N.; Ferreira, L.; Cardoso, V.; Boni, F.; Souza, A.; Gremião, M. Recent advances in smart hydrogels for biomedical applications: From self-assembly to functional approaches. Eur. Polym. J. 2018, 99, 117-133. [CrossRef]

183. Yang, Y.; Urban, M.W. Self-healing of polymers via supramolecular chemistry. Adv. Mater. Interfaces 2018, 5, 1800384. [CrossRef]

184. Meng, L.; Shao, C.; Cui, C.; Xu, F.; Lei, J.; Yang, J. Autonomous self-healing silk fibroin injectable hydrogels formed via surfactant-free hydrophobic association. ACS Appl. Mater. Interfaces 2019, 12, 1628-1639. [CrossRef]

185. Liu, J.; Tan, C.S.Y.; Yu, Z.; Li, N.; Abell, C.; Scherman, O.A. Tough supramolecular polymer networks with extreme stretchability and fast room-temperature self-healing. Adv. Mater. 2017, 29, 1605325. [CrossRef] [PubMed]

186. Wang, H.; Heilshorn, S.C. Adaptable hydrogel networks with reversible linkages for tissue engineering. Adv. Mater. 2015, 27, 3717-3736. [CrossRef] [PubMed]

187. Webber, M.J.; Appel, E.A.; Meijer, E.; Langer, R. Supramolecular biomaterials. Nat. Mater. 2016, 15, 13-26. [CrossRef] [PubMed]

188. Li, J.; Mooney, D.J. Designing hydrogels for controlled drug delivery. Nat. Rev. Mater. 2016, 1, 1-17. [CrossRef]

189. Uman, S.; Dhand, A.; Burdick, J.A. Recent advances in shear-thinning and self-healing hydrogels for biomedical applications. J. Appl. Polym. Sci. 2020, 137, 48668. [CrossRef]

190. Appel, E.; Loh, X.; Jones, S.; Biedermann, F.; Dreiss, C.; Scherman, O. High-water-content hydrogels from renewable resources through host-guest interactions. J. Am. Chem. Soc. 2012, 134, 11767-11773. [CrossRef]

191. Appel, E.A.; Loh, X.J.; Jones, S.T.; Biedermann, F.; Dreiss, C.A.; Scherman, O.A. Ultrahigh-water-content supramolecular hydrogels exhibiting multistimuli responsiveness. J. Am. Chem. Soc. 2012, 134, 11767-11773. [CrossRef] [PubMed] 
192. Park, K.; Lee, Y.; Son, J.; Bae, J.; Park, K. In situ. Supramolecular Assembly and Modular Modification of Hyaluronic Acid Hydrogels for 3D Cellular Engineering. ACS Nano 2012, 6, 2960.

193. Rodell, C.B.; MacArthur, J.W., Jr.; Dorsey, S.M.; Wade, R.J.; Wang, L.L.; Woo, Y.J.; Burdick, J.A. Shear-thinning supramolecular hydrogels with secondary autonomous covalent crosslinking to modulate viscoelastic properties in vivo. Adv. Funct. Mater. 2015, 25, 636-644. [CrossRef]

194. Appel, E.A.; del Barrio, J.; Loh, X.J.; Scherman, O.A. Supramolecular polymeric hydrogels. Chem. Soc. Rev. 2012, 41, 6195-6214. [CrossRef]

195. Guvendiren, M.; Lu, H.D.; Burdick, J.A. Shear-thinning hydrogels for biomedical applications. Soft Matter 2012, 8, 260-272. [CrossRef]

196. He, F.; Wang, L.; Yang, S.; Qin, W.; Feng, Y.; Liu, Y.; Zhou, Y.; Yu, G.; Li, J. Highly stretchable and tough alginate-based cyclodextrin/Azo-polyacrylamide interpenetrating network hydrogel with self-healing properties. Carbohydr. Polym. 2021, 256, 117595. [CrossRef]

197. Liu, F.; Li, F.; Deng, G.; Chen, Y.; Zhang, B.; Zhang, J.; Liu, C.-Y. Rheological images of dynamic covalent polymer networks and mechanisms behind mechanical and self-healing properties. Macromolecules 2012, 45, 1636-1645. [CrossRef]

198. Liu, Q.; Ji, N.; Xiong, L.; Sun, Q. Rapid gelling, self-healing, and fluorescence-responsive chitosan hydrogels formed by dynamic covalent crosslinking. Carbohydr. Polym. 2020, 246, 116586. [CrossRef]

199. Li, S.; Pei, M.; Wan, T.; Yang, H.; Gu, S.; Tao, Y.; Liu, X.; Zhou, Y.; Xu, W.; Xiao, P. Self-healing hyaluronic acid hydrogels based on dynamic Schiff base linkages as biomaterials. Carbohydr. Polym. 2020, 250, 116922. [CrossRef]

200. Zhang, S.; Huang, D.; Lin, H.; Xiao, Y.; Zhang, X. Cellulose Nanocrystal Reinforced Collagen-Based Nanocomposite Hydrogel with Self-Healing and Stress-Relaxation Properties for Cell Delivery. Biomacromolecules 2020, 21, 2400-2408. [CrossRef]

201. Furlani, F.; Sacco, P.; Cok, M.; de Marzo, G.; Marsich, E.; Paoletti, S.; Donati, I. Biomimetic, Multiresponsive, and Self-Healing Lactose-Modified Chitosan (CTL)-Based Gels Formed via Competitor-Assisted Mechanism. ACS Biomater. Sci. Eng. 2019, 5, 5539-5547. [CrossRef]

202. Barcan, G.A.; Zhang, X.; Waymouth, R.M. Structurally dynamic hydrogels derived from 1, 2-dithiolanes. J. Am. Chem. Soc. 2015, 137, 5650-5653. [CrossRef] [PubMed]

203. Lei, J.; Li, X.; Wang, S.; Yuan, L.; Ge, L.; Li, D.; Mu, C. Facile fabrication of biocompatible gelatin-based self-healing hydrogels. ACS Appl. Polym. Mater. 2019, 1, 1350-1358. [CrossRef]

204. Hafeez, S.; Ooi, H.W.; Morgan, F.L.; Mota, C.; Dettin, M.; Van Blitterswijk, C.; Moroni, L.; Baker, M.B. Viscoelastic oxidized alginates with reversible imine type crosslinks: Self-healing, injectable, and bioprintable hydrogels. Gels 2018, 4, 85. [CrossRef] [PubMed]

205. Ding, F.; Wu, S.; Wang, S.; Xiong, Y.; Li, Y.; Li, B.; Deng, H.; Du, Y.; Xiao, L.; Shi, X. A dynamic and self-crosslinked polysaccharide hydrogel with autonomous self-healing ability. Soft Matter 2015, 11, 3971-3976. [CrossRef] [PubMed]

206. Lü, S.; Gao, C.; Xu, X.; Bai, X.; Duan, H.; Gao, N.; Feng, C.; Xiong, Y.; Liu, M. Injectable and self-healing carbohydrate-based hydrogel for cell encapsulation. ACS Appl. Mater. Interfaces 2015, 7, 13029-13037. [CrossRef]

207. Song, Y.; Liu, Y.; Qi, T.; Li, G.L. Towards dynamic but supertough healable polymers through biomimetic hierarchical hydrogenbonding interactions. Angew. Chem. Int. Ed. 2018, 57, 13838-13842. [CrossRef]

208. Guo, M.; Pitet, L.M.; Wyss, H.M.; Vos, M.; Dankers, P.Y.; Meijer, E. Tough stimuli-responsive supramolecular hydrogels with hydrogen-bonding network junctions. J. Am. Chem. Soc. 2014, 136, 6969-6977. [CrossRef]

209. Wang, Y.; Huang, X.; Zhang, X. Ultrarobust, tough and highly stretchable self-healing materials based on cartilage-inspired noncovalent assembly nanostructure. Nat. Commun. 2021, 12, 1-10. [CrossRef]

210. Xu, B.; Zhang, X.; Gan, S.; Zhao, J.; Rong, J. Dual ionically cross-linked hydrogels with ultra-tough, stable, and self-healing properties. J. Mater. Sci. 2019, 54, 14218-14232. [CrossRef]

211. Izzo, D.; Palazzo, B.; Scalera, F.; Gullotta, F.; Lapesa, V.; Scialla, S.; Sannino, A.; Gervaso, F. Chitosan scaffolds for cartilage regeneration: Influence of different ionic crosslinkers on biomaterial properties. Int. J. Polym. Mater. Polym. Biomater. 2019, 68, 936-945. [CrossRef]

212. Bai, T.; Liu, S.; Sun, F.; Sinclair, A.; Zhang, L.; Shao, Q.; Jiang, S. Zwitterionic fusion in hydrogels and spontaneous and time-independent self-healing under physiological conditions. Biomaterials 2014, 35, 3926-3933. [CrossRef] [PubMed]

213. Yu, R.; Yang, Y.; He, J.; Li, M.; Guo, B. Novel supramolecular self-healing silk fibroin-based hydrogel via host-guest interaction as wound dressing to enhance wound healing. Chem. Eng. J. 2021, 417, 128278. [CrossRef]

214. Loebel, C.; Rodell, C.B.; Chen, M.H.; Burdick, J.A. Shear-thinning and self-healing hydrogels as injectable therapeutics and for 3D-printing. Nat. Protoc. 2017, 12, 1521. [CrossRef] [PubMed]

215. Chen, H.; Ma, X.; Wu, S.; Tian, H. A rapidly self-healing supramolecular polymer hydrogel with photostimulated roomtemperature phosphorescence responsiveness. Angew. Chem. 2014, 126, 14373-14376. [CrossRef]

216. Jia, Y.-G.; Jin, J.; Liu, S.; Ren, L.; Luo, J.; Zhu, X. Self-healing hydrogels of low molecular weight poly (vinyl alcohol) assembled by host-guest recognition. Biomacromolecules 2018, 19, 626-632. [CrossRef]

217. Duan, J.; Jiang, J.; Li, J.; Liu, L.; Li, Y.; Guan, C. The preparation of a highly stretchable cellulose nanowhisker nanocomposite hydrogel. J. Nanomater. 2015, 16, 75. [CrossRef] 
218. Qin, B.; Zhang, S.; Sun, P.; Tang, B.; Yin, Z.; Cao, X.; Chen, Q.; Xu, J.F.; Zhang, X. Tough and Multi-Recyclable Cross-Linked Supramolecular Polyureas via Incorporating Noncovalent Bonds into Main-Chains. Adv. Mater. 2020, 32, 2000096. [CrossRef] [PubMed]

219. Yanagisawa, Y.; Nan, Y.; Okuro, K.; Aida, T. Mechanically robust, readily repairable polymers via tailored noncovalent crosslinking. Science 2018, 359, 72-76. [CrossRef]

220. Wang, S.; Guo, G.; Lu, X.; Ji, S.; Tan, G.; Gao, L. Facile soaking strategy toward simultaneously enhanced conductivity and toughness of self-healing composite hydrogels through constructing multiple noncovalent interactions. ACS Appl. Mater. Interfaces 2018, 10, 19133-19142. [CrossRef]

221. Balakrishnan, B.; Joshi, N.; Thorat, K.; Kaur, S.; Chandan, R.; Banerjee, R. A tumor responsive self healing prodrug hydrogel enables synergistic action of doxorubicin and miltefosine for focal combination chemotherapy. J. Mater. Chem. B 2019, 7, $2920-2925$. [CrossRef]

222. Long, T.; Li, Y.; Fang, X.; Sun, J. Salt-Mediated Polyampholyte Hydrogels with High Mechanical Strength, Excellent Self-Healing Property, and Satisfactory Electrical Conductivity. Adv. Funct. Mater. 2018, 28, 1804416. [CrossRef]

223. Li, S.; Chen, C.; Zhang, Z.; Wang, D.; Lv, S. Illustration and application of enhancing effect of arginine on interactions between nano-clays: Self-healing hydrogels. Soft Matter 2019, 15, 303-311. [CrossRef] [PubMed]

224. Yuan, T.; Cui, X.; Liu, X.; Qu, X.; Sun, J. Highly tough, stretchable, self-healing, and recyclable hydrogels reinforced by in situ-formed polyelectrolyte complex nanoparticles. Macromolecules 2019, 52, 3141-3149. [CrossRef]

225. Zhang, Z.-X.; Liow, S.S.; Xue, K.; Zhang, X.; Li, Z.; Loh, X.J. Autonomous chitosan-based self-healing hydrogel formed through noncovalent interactions. ACS Appl. Polym. Mater. 2019, 1, 1769-1777. [CrossRef]

226. Liao, M.; Wan, P.; Wen, J.; Gong, M.; Wu, X.; Wang, Y.; Shi, R.; Zhang, L. Wearable, healable, and adhesive epidermal sensors assembled from mussel-inspired conductive hybrid hydrogel framework. Adv. Funct. Mater. 2017, 27, 1703852. [CrossRef]

227. Gavel, P.K.; Dev, D.; Parmar, H.S.; Bhasin, S.; Das, A.K. Investigations of peptide-based biocompatible injectable shape-memory hydrogels: Differential biological effects on bacterial and human blood cells. ACS Appl. Mater. Interfaces 2018, 10, 10729-10740. [CrossRef] [PubMed]

228. Liang, Y.; Zhao, X.; Hu, T.; Chen, B.; Yin, Z.; Ma, P.X.; Guo, B. Adhesive hemostatic conducting injectable composite hydrogels with sustained drug release and photothermal antibacterial activity to promote full-thickness skin regeneration during wound healing. Small 2019, 15, 1900046. [CrossRef]

229. Xu, J.; Wang, G.; Wu, Y.; Ren, X.; Gao, G. Ultrastretchable wearable strain and pressure sensors based on adhesive, tough, and self-healing hydrogels for human motion monitoring. ACS Appl. Mater. Interfaces 2019, 11, 25613-25623. [CrossRef]

230. Chen, J.; An, R.; Han, L.; Wang, X.; Zhang, Y.; Shi, L.; Ran, R. Tough hydrophobic association hydrogels with self-healing and reforming capabilities achieved by polymeric core-shell nanoparticles. Mater. Sci. Eng. C 2019, 99, 460-467. [CrossRef] [PubMed]

231. Liu, S.; Kang, M.; Li, K.; Yao, F.; Oderinde, O.; Fu, G.; Xu, L. Polysaccharide-templated preparation of mechanically-tough, conductive and self-healing hydrogels. Chem. Eng. J. 2018, 334, 2222-2230. [CrossRef]

232. Cheng, K.-C.; Huang, C.-F.; Wei, Y.; Hsu, S.-H. Novel chitosan-cellulose nanofiber self-healing hydrogels to correlate self-healing properties of hydrogels with neural regeneration effects. NPG Asia Mater. 2019, 11, 1-17. [CrossRef]

233. Tang, L.; Liao, S.; Qu, J. Self-healing and multistimuli-responsive hydrogels formed via a cooperation strategy and their application in detecting biogenic amines. ACS Appl. Mater. Interfaces 2018, 10, 27365-27373. [CrossRef]

234. Rodell, C.B.; Dusaj, N.N.; Highley, C.B.; Burdick, J.A. Injectable and cytocompatible tough double-network hydrogels through tandem supramolecular and covalent crosslinking. Adv. Mater. 2016, 28, 8419-8424. [CrossRef]

235. Agarwal, T.; Chiesa, I.; Presutti, D.; Irawan, V.; Vajanthri, K.Y.; Costantini, M.; Nakagawa, Y.; Tan, S.-A.; Makvandi, P.; Zare, E.N. Recent advances in bioprinting technologies for engineering different cartilage-based tissues. Mater. Sci. Eng. C 2021, 112005. [CrossRef] [PubMed]

236. Cheng, A.; Schwartz, Z.; Kahn, A.; Li, X.; Shao, Z.; Sun, M.; Ao, Y.; Boyan, B.D.; Chen, H. Advances in porous scaffold design for bone and cartilage tissue engineering and regeneration. Tissue Eng. Part B: Rev. 2019, 25, 14-29. [CrossRef] [PubMed]

237. Nematollahi, Z.; Tafazzoli-Shadpour, M.; Zamanian, A.; Seyedsalehi, A.; Mohammad-Behgam, S.; Ghorbani, F.; Mirahmadi, F. Fabrication of chitosan silk-based tracheal scaffold using freeze-casting method. Iran. Biomed. J. 2017, 21, 228. [CrossRef] [PubMed]

238. Bahrami, N.; Farzin, A.; Bayat, F.; Goodarzi, A.; Salehi, M.; Karimi, R.; Mohamadnia, A.; Parhiz, A.; Ai, J. Optimization of 3D alginate scaffold properties with interconnected porosity using freeze-drying method for cartilage tissue engineering application. Arch. Neurosci. 2019, 6, e85122. [CrossRef]

239. Prasad, A.; Sankar, M.R.; Katiyar, V. State of art on solvent casting particulate leaching method for orthopedic scaffoldsfabrication. Mater. Today: Proc. 2017, 4, 898-907. [CrossRef]

240. Jia, Z.; Liu, Y.; Wang, Y.; Peng, S.; Jia, P.; Zhang, W.; Tan, X. Gas-foaming three-dimensional electrospun nanofiber scaffold improved three-dimensional cartilage regeneration. Mater. Res. Express 2021, 8, 085403. [CrossRef]

241. Munir, N.; Callanan, A. Novel phase separated polycaprolactone/collagen scaffolds for cartilage tissue engineering. Biomed. Mater. 2018, 13, 051001. [CrossRef] [PubMed]

242. Zhou, Y.; Chyu, J.; Zumwalt, M. Recent progress of fabrication of cell scaffold by electrospinning technique for articular cartilage tissue engineering. Int. J. Biomater. 2018, 2018, 1953636. [CrossRef] 
243. Nikbakht, M.; Karbasi, S.; Rezayat, S.M.; Tavakol, S.; Sharifi, E. Evaluation of the effects of hyaluronic acid on poly (3-hydroxybutyrate)/chitosan/carbon nanotubes electrospun scaffold: Structure and mechanical properties. Polym. -Plast. Technol. Mater. 2019, 58, 2031-2040. [CrossRef]

244. Li, C.; Wang, K.; Zhou, X.; Li, T.; Xu, Y.; Qiang, L.; Peng, M.; Xu, Y.; Xie, L.; He, C. Controllable fabrication of hydroxybutyl chitosan/oxidized chondroitin sulfate hydrogels by 3D bioprinting technique for cartilage tissue engineering. Biomed. Mater. 2019, 14, 025006. [CrossRef]

245. Kundu, J.; Shim, J.H.; Jang, J.; Kim, S.W.; Cho, D.W. An additive manufacturing-based PCL-alginate-chondrocyte bioprinted scaffold for cartilage tissue engineering. J. Tissue Eng. Regen. Med. 2015, 9, 1286-1297. [CrossRef]

246. Semba, J.A.; Mieloch, A.A.; Rybka, J.D. Introduction to the state-of-the-art 3D bioprinting methods, design, and applications in orthopedics. Bioprinting 2020, 18, e00070. [CrossRef]

247. Zhu, W.; Qu, X.; Zhu, J.; Ma, X.; Patel, S.; Liu, J.; Wang, P.; Lai, C.S.E.; Gou, M.; Xu, Y. Direct 3D bioprinting of prevascularized tissue constructs with complex microarchitecture. Biomaterials 2017, 124, 106-115. [CrossRef]

248. Roseti, L.; Cavallo, C.; Desando, G.; Parisi, V.; Petretta, M.; Bartolotti, I.; Grigolo, B. Three-dimensional bioprinting of cartilage by the use of stem cells: A strategy to improve regeneration. Materials 2018, 11, 1749. [CrossRef]

249. Zhao, P.; Gu, H.; Mi, H.; Rao, C.; Fu, J.; Turng, L.-s. Fabrication of scaffolds in tissue engineering: A review. Front. Mech. Eng. 2018, 13, 107-119. [CrossRef]

250. Facklam, A.L.; Volpatti, L.R.; Anderson, D.G. Biomaterials for personalized cell therapy. Adv. Mater. 2020, 32, 1902005. [CrossRef]

251. Fox, I.J.; Daley, G.Q.; Goldman, S.A.; Huard, J.; Kamp, T.J.; Trucco, M. Use of differentiated pluripotent stem cells in replacement therapy for treating disease. Science 2014, 345. [CrossRef] [PubMed]

252. Arbabi, V. Multi-Physics Computational Models of Articular Cartilage for Estimation of Its Mechanical and Physical Properties. Ph.D. Thesis, Delft University of Technology, Delft, The Netherlands, 2016.

253. Pearce, D.; Fischer, S.; Huda, F.; Vahdati, A. Applications of computer modeling and simulation in cartilage tissue engineering. Tissue Eng. Regen. Med. 2020, 17, 1-13. [CrossRef] [PubMed] 